\title{
Non-autophagy role of Atg5 and NBR1 in unconventional secretion of IL-12 prevents gut dysbiosis and inflammation
}

Seth D. Merkley,\#, Samuel M. Goodfellow ${ }^{2, \#, ~ Y a n ~ G u o 1, ~ Z o e ~ E . R . ~ W i l t o n ¹, ~ J a n i e ~ R . ~ B y r u m ³ ~}{ }^{3}$, Kurt C. Schwalm ${ }^{4}$, Darrell L. Dinwiddie ${ }^{4,5}$, Rama R. Gullapalli6, Vojo Deretic ${ }^{3,7}$, Anthony Jimenez Hernandez ${ }^{1}$, Steven B. Bradfute ${ }^{2}$, Julie G. $\operatorname{In}^{1,8}$ and Eliseo F. Castillo*1,5,7

${ }^{1}$ Division of Gastroenterology and Hepatology, Department of Internal Medicine, University of New Mexico Health Sciences, Albuquerque, NM.

${ }^{2}$ Center for Global Health, Department of Internal Medicine, University of New Mexico Health Sciences, Albuquerque, New Mexico.

${ }^{3}$ Department of Molecular Genetics and Microbiology, University of New Mexico Health Sciences, Albuquerque, NM.

${ }^{4}$ Department of Pediatrics, University of New Mexico Health Sciences, Albuquerque, NM.

${ }^{5}$ Clinical and Translational Science Center, University of New Mexico Health Sciences, Albuquerque, New Mexico.

${ }^{6}$ Department of Pathology, University of New Mexico Health Sciences, Albuquerque, NM.

${ }^{7}$ Autophagy Inflammation and Metabolism Center of Biomedical Research Excellence, University of New Mexico Health Sciences, Albuquerque, NM.

${ }^{8}$ Division of Gastroenterology and Hepatology, Department of Medicine, Johns Hopkins University School of Medicine, Baltimore, MD.

\#Authors contributed equally to this study

${ }^{*}$ Correspondence should be addressed to: ecastillo@salud.unm.edu (E.F.C.)

Running title: Atg5 limits IL-12-mediated inflammation

Keywords: autophagy, macrophages, inflammation, cytokines, microbiota 


\section{ABSTRACT}

Intestinal myeloid cells play a critical role in balancing intestinal homeostasis and inflammation. Here, we report that expression of the autophagy related 5 (Atg5) protein in myeloid cells prevents dysbiosis and excessive intestinal inflammation by limiting IL-12 production. Mice with a selective genetic deletion of Atg5 in myeloid cells (Atg5 $\Delta$ Mye) showed signs of dysbiosis prior to colitis and exhibited severe intestinal inflammation upon colitis induction that was characterized by increased IFNy production. This increase in IFNy was due to excess IL-12 secretion from Atg5-deficient myeloid cells. Atg5 functions to limit IL-12 secretion through modulation of late endosome (LE) acidity. Additionally, the autophagy cargo receptor NBR1, which accumulates in Atg5-deficient cells, played a role by delivering IL-12 to LE. Restoration of the intestinal microbiota and alleviation of intestinal inflammation was achieved by genetic deletion of IL-12 in Atg5 $\Delta$ Mye mice. In summary, Atg5 expression in intestinal myeloid cells acts as an anti-inflammatory brake to regulate IL-12 thus preventing dysbiosis and uncontrolled IFNy-driven intestinal inflammation.

\section{INTRODUCTION}

Immune system dysregulation, intestinal barrier defects and dysbiosis are believed to be driven in part by genetics according to recent genome-wide association studies (GWAS) (Schirmer, Garner et al., 2019). Many of the identified genes are involved in innate cell bacterial recognition and processing and appear to contribute to the pathogenesis observed in inflammatory bowel disease (IBD) such as NOD2 and ATG16L1 which are linked to autophagy (Schirmer et al., 2019). Autophagy is one such process associated with IBD susceptibility (Brest, Lapaquette et al., 2011, Hampe, Franke et al., 2007, Henckaerts, Cleynen et al., 2011, Lahiri, Hedl et al., 2015, Lassen \& Xavier, 2018, Levine \& Kroemer, 2019, McCarroll, Huett et al., 2008, Rioux, Xavier et al., 2007, Roberts, Gearry et al., 2007, Yamazaki, Onouchi et al., 2007). Autophagy is a conserved catabolic process that degrades protein aggregates, damaged organelles and numerous pathogens (Galluzzi, Baehrecke et al., 2017). Autophagy has proven critical for intestinal homeostasis. Defects in the autophagic pathway, specifically in intestinal epithelial cell lineages, results in increased intestinal permeability and Paneth and Goblet cell (GC) dysfunction (Cadwell, Liu et al., 2008, Cadwell, Patel et al., 2009, Matsuzawa-Ishimoto, Shono et al., 2017, Nighot, Hu et al., 2015, Patel, Miyoshi et al., 2013, Wong, Ganapathy et al., 2019). More recently, an IBD risk loci associated with autophagy was found to disrupt the microbiota 
albeit it is unclear what cell-type mediates this effect (Lavoie, Conway et al., 2019). Nevertheless, there is mounting evidence that autophagic genes are critical for intestinal homeostasis and defects in the autophagic process can lead to increased susceptibility to intestinal pathogens and overall enhanced IBD susceptibility (Bel, Pendse et al., 2017, Benjamin, Sumpter et al., 2013, Burger, Araujo et al., 2018, Lassen \& Xavier, 2018).

Many of these IBD risk genes and pathways including autophagy are highly relevant to myeloid cell function in addition to that of epithelial cells (Chauhan, Mandell et al., 2015, Homer, Richmond et al., 2010, Singh, Davis et al., 2006, Zhang, Zheng et al., 2017). However, the specific role for autophagy and autophagy genes in myeloid cells in maintaining the balance between intestinal homeostasis and inflammation has yet to be fully explored. The prevailing hypothesis linking autophagy to IBD is through the IL-17 signaling pathway. IL-1, IL-17 and IL23, all involved in IL-17-mediated inflammation, are upregulated in IBD (Angelidou, Chrysanthopoulou et al., 2018, Coccia, Harrison et al., 2012, Dragasevic, Stankovic et al., 2018, Jiang, Su et al., 2014, Kanai, Mikami et al., 2012, Liu, Yadav et al., 2011, Mao, Kitani et al., 2018, Menghini, Corridoni et al., 2019, Moschen, Tilg et al., 2019, Shouval, Biswas et al., 2016). Our previous work as well as that of others has demonstrated that autophagy regulates the production of the proinflammatory cytokines IL-1 $\alpha$, IL-1 $\beta$ and IL-23, primarily in infection models (Castillo, Dekonenko et al., 2012, Dupont, Jiang et al., 2011, Peral de Castro, Jones et al., 2012, Reed, Morris et al., 2015, Watson, Manzanillo et al., 2012, Zhang, Kenny et al., 2015). This observation is the canonical pathway frequently described linking autophagy dysregulation to excess inflammation via IL-1 and IL-17. IL-1 and IL-23 are key regulators of IL-17-mediated inflammation (Chung, Chang et al., 2009, McGeachy, Chen et al., 2009). However, the role of IL-17 in IBD pathogenesis has recently been questioned as therapeutic targeting of IL-17 exacerbates inflammation in both IBD patients and animal models of IBD (Fujino, Andoh et al., 2003, Hueber, Sands et al., 2012, Ogawa, Andoh et al., 2004, Targan, Feagan et al., 2016, Yang, Chang et al., 2008), suggesting that IL-17 may not be the predominant driver of autophagy-linked IBD pathogenesis. Thus, there is a clear gap in knowledge regarding which inflammatory pathway might underlie IBD pathology with respect to autophagy dysregulation.

This study assessed the role of the autophagy gene Atg5 in myeloid cells in maintaining the balance between intestinal homeostasis and inflammation. Atg5's most well-understood actions are via the Atg5-Atg12-Atg16L1 complex, which acts as the E3 enzyme conjugating PE to LC3, and along with the E1-like actions of Atg7 and the E2-like actions of Atg3, this pathway drives isolation membrane formation and eventual autophagosome maturation (Hanada, Noda 
et al., 2007, Mizushima, Noda et al., 1998, Noda, Fujioka et al., 2013, Sakoh-Nakatogawa, Matoba et al., 2013). Atg5 is also embedded in autophagosomal membranes which allows it to interact with fusion proteins in lysosomal membranes such as Tectonic $\beta$-propeller repeat containing 1 (TECRP) that facilitate autophagosome-lysosome fusion (Chen, Fan et al., 2012, Ye, Zhou et al., 2018). Thus, Atg5 plays a major role in selective and bulk autophagy which are critical for cell-autonomous immunity. However, it is unclear how Atg5 expression, specifically in myeloid cells, functions outside of bacterial recognition and processing. Here, we show at steady state that mice with an Atg5-deficiency in myeloid cells (herein called Atg5 $\Delta$ Mye mice) (Castillo et al., 2012, Zhao, Fux et al., 2008) show alterations in the gut microbiota as well as mucosal TH1 (IFNy) skewing. Atg5 $\Delta$ Mye mice were susceptible to chemically induced colitis that was characterized by an enhanced IFNy response. Both $\mathrm{TH} 1$ skewing and microbiota changes were partly driven through IL-12 dysregulation in Atg5-deficient myeloid cells. Confirming our findings, Atg5 $\Delta$ Mye mice crossed to IL12p35-deficient mice resulted in restoration of the gut microbiota and protection from dextran sodium sulfate (DSS)-induced colitis through the reduction of the IL-12 pathway. We further show IL-12 regulation was not mediated through autophagy but interactions with sequestosome-1-like receptor NBR1 and Atg5 action on late endosomes (LE). There has not been a single description of autophagic proteins regulating IL-12-driven immune responses. Thus, these data indicate a new autophagyindependent role for Atg5 and NBR1 in myeloid cells in influencing intestinal homeostasis through an IL-12 pathway.

\section{RESULTS}

\section{Altered colonic microbiota in mice with an Atg5-deficiency in myeloid cells.}

The gut microbiota is influenced by environmental factors, immune responses, and genetics which is highlighted in individuals with IBD. Numerous studies have reported a decrease in bacterial diversity in IBD patients with major alterations in the phyla Firmicutes and Bacteroidetes (Imhann, Vich Vila et al., 2018, Kang, Alvarado et al., 2020, Manichanh, Borruel et al., 2012, Manichanh, Rigottier-Gois et al., 2006, Ni, Wu et al., 2017, Willing, Dicksved et al., 2010). There is substantial evidence that intestinal myeloid cells are regulated by commensal microbiota (Bain, Bravo-Blas et al., 2014, Chang, Hao et al., 2014, Kang et al., 2020, Mortha, Chudnovskiy et al., 2014, Singh, Gurav et al., 2014); however, numerous studies have emerged demonstrating myeloid regulation of the microbiota (Bader, Enos et al., 2018, Niess, Brand et al., 2005, Rescigno, Urbano et al., 2001, Vallon-Eberhard, Landsman et al., 2006). Autophagy genes appear to be involved in the latter as it was shown the autophagy protein, Atg16L1, 
expressed in myeloid cells from both humans and mice altered IgA-coated intestinal bacteria at steady-state and during inflammation (Zhang et al., 2017); however, it was not confirmed if this increase in IgA-coated bacteria affects the overall microbial community. More recently, another mouse model with a global knockin of the IBD risk allele ATG16L1 T300A had an altered gut microbiota prior to colitis induction (Lavoie et al., 2019).

Utilizing Atg5 $\Delta$ Mye mice (myeloid specific loss of autophagy related 5, Atg5, gene), we investigated the importance of Atg5 expression in myeloid cells in maintaining the intestinal microbiota (Castillo et al., 2012, Zhao et al., 2008). In comparison to littermate controls (Atg5Wild-type, Atg5-Wt), Atg5 $\Delta$ Mye mice showed significant differences in the intestinal microbial composition (Fig. 1 A). Similar to what is observed in IBD patients (Manichanh et al., 2012, Manichanh et al., 2006, Ni et al., 2017, Seksik, 2010, Willing et al., 2010), Atg5 $\Delta$ Mye mice had a decrease in the phylum Firmicutes (Fig. 1 B) and an increase in the phylum Bacteroidetes (Fig. $1 \mathrm{C})$ compared to Atg5-Wt mice. No significant changes were observed for phyla Actinobacteria and Proteobacteria (Fig. 1, D and E). Additionally, the principal coordinate analysis (PCoA) plot and heatmap of bacterial communities revealed tight clustering of Atg5-Wt microbiota that was distinct from Atg $5 \Delta$ Mye microbiota at the genus level (Fig. 1, F and $\mathrm{G}$ ) and this was also observed for female mice (Supp. Fig. $1 \mathrm{~A}$ and $\mathrm{B}$ ). Thus, Atg5 expression in myeloid cells is critical for the maintenance of the intestinal microbiota.

\section{Myeloid Atg5 expression regulates IFNy response in the intestinal microenvironment.}

The proinflammatory cytokine IL-17 contributes to shaping and regulating the intestinal microbiota. We and others have shown T cells from mice wherein myeloid cells lack Atg5 or other autophagy-related genes display skewing towards IL-17 polarization (Castillo et al., 2012, Peral de Castro et al., 2012, Reed et al., 2015, Watson et al., 2012). This T cell polarization is mediated through the dysregulation of cytokines or cellular components that promote IL-17 responses (Chung et al., 2009, McGeachy et al., 2009). Microbiota differences can also alter T cell polarization (Atarashi, Tanoue et al., 2011, Chen, Sun et al., 2019, Ivanov, Atarashi et al., 2009, Ivanov, Frutos Rde et al., 2008, Sun, Wu et al., 2018). To determine whether an enhanced level of IL-17-producing $T$ cells populating the intestinal mucosa is influencing the microbiota of Atg5 $\Delta$ Mye mice, we isolated and stimulated $\mathrm{CD} 4^{+} \mathrm{T}$ cells from the mesenteric lymph nodes ( $\mathrm{mLN}$ ) to determine $\mathrm{TH}$ polarization. Interestingly, we observed an increase in IFNy-producing $\mathrm{CD}^{+}{ }^{+} \mathrm{T}$ cells from Atg5 $\Delta$ Mye mice (Supp. Fig. $1 \mathrm{C}, \mathrm{D}$ ) with no significant 
difference in the number of IL-17-producing CD4 ${ }^{+}$T cells (Supp. Fig. $1 \mathrm{E}$ ). Thus, at steady state, Atg5 $\triangle$ Mye mice show differences in $\mathrm{CD}^{+} \mathrm{T}$ cell polarization.

To examine the impact of $\mathrm{TH} 1$ skewing and microbiota alteration in Atg5 $\Delta$ Mye mice during an inflammatory state, we subjected both Atg5 $\Delta$ Mye and Atg5-Wt mice to DSS-induced acute colitis. Similar to what was reported in mice with an Atg16/1- or Atg7-deficiency specifically in myeloid cells (Lee, Kim et al., 2016a, Zhang et al., 2017), colitis induction in Atg5 $\Delta$ Mye mice resulted in an exacerbated inflammatory response compared to Atg5-Wt mice. Intestinal epithelial disruption via DSS caused significant weight loss (Fig. 2 A) as well as acute diarrheal response and mucosal bleeding (disease activity index, DAI, Fig. 2 B) in Atg5 $\Delta$ Mye mice. The length of the colon was measured to assess colonic mucosal injury and revealed colonic shortening and severe inflammation from the cecum to the distal colon of Atg5 $\Delta$ Mye mice (Fig. 2 C and Supp. Fig. 1, F and G). Additionally, we found that the spleen weight of colitic Atg5 $\Delta$ Mye mice was increased (Fig. $2 \mathrm{D}$ ). These results indicate Atg5 expression in myeloid cells, like Atg7 and Atg16L1, is critical to control acute intestinal inflammation.

The acute DSS model is an innate/wound repair model and although the acute DSS model is not solely dependent on $B$ and $T$ cell responses, both participate in the exaggerated presentation of the disease. In fact, T cells have been shown to be the major driver of colonic inflammation in the acute DSS model by day 4 with a peak at day 8 (Nunes, Kim et al., 2018). Interestingly, we do not see major changes in DAl in Atg5 $\Delta$ Mye mice until day 6 and 7 (Fig. 2B) when we would expect T cells to be responding. Furthermore, IFNy has been shown to play an indispensable role in the initiation of acute DSS colitis and IFNy-deficient mice are protected from acute DSS induced colitis (Ito, Shin-Ya et al., 2006). Thus, this model is sufficient to show IFNy responses from $T$ cells in Atg5 $\Delta$ Mye mice. Our observation that $C D 4^{+} \mathrm{T}$ cells are skewed towards a type 1 immune response in Atg5 $\Delta$ Mye mice at steady state prompted an examination of cytokine expression and $\mathrm{TH}$ skewing during colitis. Colitic colons from Atg5 $\Delta$ Mye mice showed increased IFNy gene and protein expression compared to controls (Fig. 2, E and G). Similar to steady state, there was also an increase in IFNy-producing CD4 ${ }^{+} \mathrm{T}$ cells isolated from the $\mathrm{mLN}$ of colitic Atg $5 \Delta$ Mye mice (Fig. $2 \mathrm{I}$ ). While IL-17 was expressed in both Atg $5 \Delta$ Mye and Atg5-Wt mice, we found no significant difference in IL-17 expression in the colon (Fig. 2, F and $\mathrm{H}$ ) or from mLN CD4+ ${ }^{+}$cells (Fig. $2 \mathrm{~J}$ ). This discrepancy in IL-17 expression could be tissuespecific as models in which myeloid cells lack autophagic components and express high levels of IL-17 have been reported for respiratory infections (Castillo et al., 2012, Reed et al., 2015, Watson et al., 2012). However, others have reported TH1 skewing in ATG16L1T300A knockin mice as well as in conditional myeloid Atg7-deficient mice during intestinal inflammation (Lavoie 
et al., 2019, Zhang et al., 2017). Thus, our data suggest Atg5 expression in myeloid cells protects the intestinal microenvironment during inflammation through limiting IFNy expression.

\section{Atg5 limits IL-12 production in myeloid cells independent of canonical autophagy.}

The current paradigm is that an autophagic defect (or loss of an autophagy-related gene) in myeloid cells leads to enhanced IL-1 $\alpha / \beta$ expression (Castillo et al., 2012, Dupont et al., 2011, Peral de Castro et al., 2012). The excess production of IL-1 skews lymphocytes to produce IL17 , subsequently promoting IL-17-mediated inflammation. However, we found colitic Atg5 $\Delta$ Mye mice presented with increased IFNy and no significant difference in IL-17 in the colon microenvironment. This suggests colonic Atg5-deficient myeloid cells are likely to produce other factors that promote TH1 skewing and IFNy production. IL-12p70 (hereafter called IL-12) is a major cytokine involved in TH1 polarization and is a potent inducer of IFNy (Eftychi, Schwarzer et al., 2019, Moschen et al., 2019, Perussia, Chan et al., 1992, Trinchieri, Wysocka et al., 1992). IL-12 is a heterodimeric protein comprised of IL-12p35 and IL-12p40 (IL-12p40 also dimerizes with IL-23p19 to form IL-23, a major cytokine maintaining TH17 cells) and is highly expressed by various myeloid cells including macrophages (Abdi \& Singh, 2015, Carra, Gerosa et al., 2000, D'Andrea, Rengaraju et al., 1992, Moschen et al., 2019, Reitberger, Haimerl et al., 2017). We have previously shown Atg5 $\Delta$ Mye mice also produce excess IL-12 during tuberculosis infection (Castillo et al., 2012). Utilizing bone marrow-derived macrophages (BMM) from Atg5 $\Delta$ Mye and Atg5-Wt mice, we showed that Atg5-deficient macrophages secrete excess IL-12 upon LPS/IFN-y stimulation compared to Atg5-Wt macrophages (Fig. 3A). For many cell types, low levels of IL-12p35 are constitutively expressed, while IL-12p40 expression occurs primarily in macrophages and dendritic cells, and both increase in response to microbial stimulation (Abdi \& Singh, 2015, Carra et al., 2000, D'Andrea et al., 1992, Reitberger et al., 2017). We observed no difference in $/ / 12 a$ (IL-12p35) and //12b (IL-12p40) gene expression (Supp. Fig. 2, A and B). Furthermore, there was no difference in cell surface expression of IFNy-receptor, TLR4/MD2 or CD14 between Atg5-Wt and Atg5-deficient BMM (Supp. Fig. 2 C) that would enable an enhanced response. This data suggests Atg5 has a post-transcriptional role in regulating IL-12 secretion.

As mentioned above, Atg5 assists in autophagosome formation and autophagosomelysosome fusion. Thus, the genetic deletion of Atg5 would consequently affect several steps in autophagy. We next considered whether IL-12 was a direct target for autophagic removal. However, endogenous IL-12 and LC3 did not colocalize during stimulation and treatment with bafilomycin A1 (Baf. A1) (Supp. Fig. 2 D) in Atg5-Wt or Atg5-deficient BMM suggesting IL-12 is 
unlikely to be a direct target for autophagic degradation. Baf. A1 is widely used to inhibit autophagic flux by targeting the V-ATPase ATP6V0C/V0 subunit c but can also deacidify endosome/lysosome vesicles through the same mechanism (Harada, Shakado et al., 1997, Yoshimori, Yamamoto et al., 1991). Atg5 also regulates acidification and deacidification of late endosomal compartments (Guo, Chitiprolu et al., 2017) and prior to stimulation Atg5-deficient BMM display increased lysotracker staining compared to Atg5-Wt BMM (Supp Fig. 2E) suggesting the loss of Atg5 affects the regulation of vesicles' pH levels (Guo et al., 2017, Peng, Zhang et al., 2014). Interestingly, Baf. A1 treatment decreased IL-12 secretion in Atg5-Wt BMM (Fig. 3 B). Furthermore, treatment of Atg5-deficient BMM with Baf. A1 also reduced IL-12 secretion (Fig. $3 \mathrm{C}$ ). These data suggest Atg5 regulates IL-12 secretion through vesicle acidification and Baf. A1 can compensate for the loss of Atg5 in regulating IL-12 secretion.

We next examined the intracellular localization of IL-12 after Baf. A1 treatment. As mentioned above, IL-12 consists of subunits IL-12p35 and IL-12p40. While the IL-12p40 subunit has conventional secretory sequences and can be secreted in its homodimeric form, the IL12 p35 peptide is leaderless, cannot be secreted as a monomer, and conventional secretion cannot be induced by the addition of a secretory sequence (Abdi \& Singh, 2015, Carra et al., 2000, Reitberger et al., 2017). The purpose of IL-12p35's constitutive expression remains poorly understood (Abdi \& Singh, 2015) but a recent report demonstrated IL-12p35 is trafficked to late endosomes (LE) before secretion (Chiaruttini, Piperno et al., 2016). As observed with total IL12, Baf. A1 treatment resulted in IL-12p35 accumulation in LE as determined by IL-12p35 (red) and Lamp1 (green) colocalization (Fig. 3 D). White arrows in images indicate puncta colocalizing with insets displaying enlargement of indicated region. Interestingly, IL-12p35 (green) colocalized with Atg5 (red) (Fig. 3 E). IL-12 (red) colocalization with Lamp1 (green) was more evident in Atg5-deficient BMM (Fig. 3 F). Further analysis, revealed IL-12 (red) also colocalized with the LE marker Rab7 (green) (Supp. Fig. 2F) as previously reported (Chiaruttini et al., 2016). Taken together, our data suggest Lamp1+ LEs (Cheng, Xie et al., 2018, Dunster, Toh et al., 2002) contain IL-12 and the lack of Atg5 leads to increased levels of IL-12 in these vesicles.

\section{The sequestosome-1-like receptor NBR1 is involved in IL-12 secretion.}

While most cytokines are directed by their signal sequence through endoplasmic reticulum (ER)-golgi complex pathway for processing and trafficking, some inflammatory cytokines, including IL-1 $\beta$ and IL-18, are known to be excreted via alternative strategies (Abdel Fattah, Bhattacharya et al., 2015, Claude-Taupin, Bissa et al., 2018, Dupont et al., 2011, Kimura, Jia et al., 2017, Murai, Okazaki et al., 2015). For IL-1 $\beta$, the selective autophagy cargo receptor TRIM16 directs IL-1 $\beta$ to LC3-II+ sequestration membranes for secretion (Kimura et al., 2017). 
This suggests other selective cargo receptors such as the sequestosome-1-like receptors (SLRs: p62/SQSTM1 and NBR1) could act as possible cargo receptors for alternative secretion (Claude-Taupin, Jia et al., 2017, Jiang, Dupont et al., 2013). We considered NBR1 might be responsible for delivering IL-12 to LE for secretion given a homolog of the mammalian NBR1, Nbr1 from Schizosaccharomyces pombe was shown to deliver proteins to LE (Mardakheh, Yekezare et al., 2009) and NBR1 accumulates upon autophagy inhibition (Kirkin, Lamark et al., 2009). Indeed, confocal imaging revealed NBR1 (red) co-localized with IL-12p35 (green) in WT BMM after LPS/IFN-y and Baf. A1 treatment (Fig. 4 A, top row and B); white arrows indicate puncta co-localizing. However, this co-localization was reduced upon brefeldin A (BrefA) treatment, suggesting NBR1 (red) and IL-12 (green) interaction occurs after IL-12 leaves the ER (Fig. $4 \mathrm{~A}$, bottom row and $\mathrm{B}$ ). This reduction in colocalization was not due to enhanced secretion as IL-12 was undetectable by ELISA after LPS/IFNy/brefA treatment (data not shown). To verify NBR1/IL-12 interaction in macrophages, cell lysates were immunoprecipitated with antiIL12p35, anti-NBR1 or isotype control antibodies and subjected to western blot with anti-IL12p35, anti-IL-12p40, anti-NBR1 and anti-p62 antibodies. Both IL-12p40 and NBR1 coprecipitated with anti-IL-12p35 antibodies (Fig. 4 C). Reciprocally, IL-12p35 and IL-12p40 coprecipitated with anti-NBR1 antibodies (Fig. 4 C); however, neither probe co-precipitated p62/SQSTM1 (Fig. 4C). This interaction was further verified in silico through ClusPro docking (Kozakov, Hall et al., 2017) as IL-12 (1F45) interacted with multiple peptide fragments (1WJ6, 2L8J, 2MGW, and 2MJ5) of NBR1 (Fig. 4 D and E). Lastly, a knock down of NBR1 via small interfering RNA (siRNA) in Atg5-Wt BMM reduced IL-12 secretion compared to scrambled siRNA control (Fig. 4 F, Supp. Fig. 2 G). A reduction in IL-12 secretion was also observed in Atg5-deficient BMM after NBR1 knockdown suggesting this interaction is independent of Atg5

(Fig. 4 G, Supp. Fig. 2 G). Taken together, our data suggest NBR1 is partially responsible for IL12 secretion whereby it functions to direct IL-12p35 to LE for secretion.

\section{Limiting IL-12 secretion restores the gut microbiota and protects against DSS-induced colitis in mice with an Atg5-deficiency in myeloid cells.}

To determine if the change in the gut microbiota and susceptibility to DSS-induced colitis in Atg5 $\Delta$ Mye mice was due to the excess IL-12 secretion, we crossed Atg5 $\Delta$ Mye mice to IL-12p35 deficient mice (Mattner, Magram et al., 1996) to generate Atg5 $\Delta$ Mye-IL12KO mice. We first examined the colonic microbiota at steady state in all three groups of mice (i.e. Atg5-Wt, Atg5 $\Delta$ Mye and Atg5 $\Delta$ Mye-IL12KO). Atg5 $\Delta$ Mye-IL12KO mice showed a global change in the intestinal microbial composition in comparison to Atg5 $\Delta$ Mye mice, particularly an increase in the 
phyla Firmicutes (Supp. Fig. 3 A). Furthermore, the PCoA plots and heatmap show clustering of the bacterial communities (genus level) of the Atg5 $\Delta$ Mye-IL12KO and Atg5-Wt colonic mice that was separated from the bacterial community in the Atg5 $\Delta$ Mye mice (Fig. 5, A and B).

We next examined Atg5 $\Delta$ Mye-L12KO mice response to DSS-induced colitis. Atg5 $\Delta$ MyeIL12KO mice were protected from DSS-induced colitis compared to Atg5 $\Delta$ Mye mice. Atg $5 \Delta$ MyeIL12KO mice suffered minimal weight loss, showed no shortening of the colon after colitis induction, and had reduced spleen weights (Fig. 5, C-E). There was also a decrease in Ifng gene expression in the colon after colitis induction in Atg5 $\Delta$ Mye-IL12KO mice but no change in II17a gene expression between both groups of mice. (Supp. Fig. 3, B and C). Additionally, we observed a decrease in the percent of IFNy-producing CD4 ${ }^{+} \mathrm{T}$ cells from the $\mathrm{mLN}$ of Atg5 $\Delta$ MyeIL12KO mice compared to Atg5 $\Delta$ Mye mice (Fig. 5 F). However, Atg5 $\Delta$ Mye-IL12KO mLN CD4 ${ }^{+}$ T cells did produce more IL-17 (Fig. 5 G). This change in IL-17 expression is likely due to Atg5deficient myeloid cells producing excess IL-1 (Castillo et al., 2012). Nevertheless, genetic deletion of IL-12p35 from mice in which myeloid cells also lack Atg5 restores the microbiota and protects against DSS-induced colitis.

\section{DISCUSSION}

This work identifies a role for Atg5 in myeloid cells in unconventional cytokine secretion that consequently affects intestinal homeostasis. Additionally, it adds to the plethora of functions described for Atg5 (Guo et al., 2017, Inomata, Into et al., 2013, Lee, Mattei et al., 2010, Ndoye, Budina-Kolomets et al., 2017, Peng et al., 2014, Simon, Yousefi et al., 2014, Yousefi, Perozzo et al., 2006). Along with these studies, this work establishes a new non-autophagy, immunological role for Atg5 in promoting TH1 responses. In the context of IBD and autophagyrelated proteins (Atg), GWAS has only identified ATG16L1 variants (Hampe et al., 2007). Nevertheless, animal models with an Atg5-deficiency display a similar phenotype to Atg16L1deficient mice (Cadwell et al., 2009). Interestingly, the levels of ATG5 and the function of autophagy (and possibly other ATG5 functions) are decreased in IBD patient samples. This decrease in ATG5 expression and autophagy activity in IBD patients is linked to an increased expression of the microRNA miR30C that acts to downregulate ATG5 expression (Nguyen, Dalmasso et al., 2014, Ye et al., 2018). Therefore, inhibiting Atg5 expression and function, described here in only myeloid cells, ultimately alters the intestinal microenvironment.

As previously reported, Atg5-deficient myeloid cells produce excess proinflammatory cytokines including IL-1 $\alpha$ and IL-1 $\beta$ (Castillo et al., 2012, Dupont et al., 2011). Thus, we cannot dismiss that either cytokine contributes to the excess IFNy observed in Atg5cKO mice as IL-1 
can synergize with IL-12 to enhance IFNy production and TH1 skewing (Cooper, Fehniger et al., 2001, Tominaga, Yoshimoto et al., 2000). Although we and others did not find any changes in colonic IL-17-producing cells in mice with a genetic deletion of Atg5 or Atg7 in myeloid cells (Castillo et al., 2012, Lee et al., 2016a), both colonic TH17 and TH1 cells were found to be increased in ATG16L1 T300A knockin mice (Lavoie et al., 2019). Given Atg5 $\triangle$ Mye-IL12KO mice were protected against colitis induction, these results together suggest IL-12 is a key cytokine driving intestinal pathology and $\mathrm{TH} 1$ skewing in our model.

This similarilty in intestinal TH1 responses between these mouse models is likely linked to the functional role of Atg5, Atg7 and Atg16L1. All three proteins are involved in some aspect of the autophagy process as well as endosome and lysosome regulation (Fraser, Simpson et al., 2019, Galluzzi et al., 2017, Mardakheh et al., 2009). The role of the TH17 response in driving intestinal pathology is up for debate as there is strong evidence suggesting IL-17 may have a protective role in the intestine. Exacerbated intestinal inflammation was reported in I/17adeficient mice or after in vivo blockade of IL-17 during DSS-induced colitis (Ogawa et al., 2004, Yang et al., 2008). Furthermore, in clinical trials for IBD patients, targeting IL-17 or IL-17R worsened symptoms leading to early clinical trial termination (Hueber et al., 2012, Targan et al., 2016). Nevertheless, this does not rule out the effects of increased levels of IL-17 during intestinal inflammation (Fujino et al., 2003, Jiang et al., 2014, Moschen et al., 2019). In fact, IL17 plays a major role in regulating mucosal IgA production (Dann, Manthey et al., 2015, Kumar, Monin et al., 2016). Interestingly, increased IgA-coated bacteria were found in mice that lack Atg16L1 in myeloid cells as well as in the stool of Crohn's disease patients who were homozygous for the ATG16L1 T300A risk allele (Zhang et al., 2017). ATG16L1 T300A knockin mice also showed alteration in the microbiota. Similar to our findings, ATG16L1 T300A knockin mice also had a decrease in the phyla Firmicutes and an increase in the phyla Bacteroidetes (Lavoie et al., 2019). It is unclear if these microbiota changes in ATG16L1 T300A knockin mice are due specifically to myeloid cells, since all cells including the intestinal epithelium express the ATG16L1 T300A gene in this mouse model. Additionally, deletions or polymorphisms of autophagy genes in myeloid cells alter bacterial clearance suggesting there are multiple mechanisms by which autophagy genes regulate host-microbiota interactions. Our data suggest myeloid cells likely have a strong contribution in maintaining the microbiota through Atg5's action on IL-12 secretion.

The autophagic process and the genes that regulate autophagy are crucial for intestinal homeostasis. Autophagy is required for the maintenance of tight junction integrity, gutcommensal homeostasis, and control of invasive bacteria at the intestinal epithelium (Bel et al., 
2017, Benjamin et al., 2013, Burger et al., 2018, Cadwell et al., 2008, Cadwell et al., 2009, Lee et al., 2016a, Matsuzawa-Ishimoto et al., 2017, Nighot et al., 2015, Patel et al., 2013, Wong et al., 2019, Wu, Wang et al., 2017). Multiple lines of evidence also suggest autophagy regulates inflammatory cytokines (Castillo et al., 2012, Dupont et al., 2011, Lee, Foote et al., 2016b, Merkley, Chock et al., 2018, Saitoh, Fujita et al., 2008). These attributes make modulation of autophagy or single autophagic proteins an excellent therapeutic target. Nevertheless, it is critical to understand the function of these individual proteins given they can modulate different TH responses. In fact, reagents that are known to target autophagy activation such as rapamycin, increase IL-12 secretion (Macedo, Turnquist et al., 2013, Ohtani, Nagai et al., 2008). Additionally, chloroquine, a known inhibitor of autophagosome-lysosome fusion, reduces IL-12 secretion (Said, Bock et al., 2014), likely through a similar mechanism as Baf. A1. These reagents have been used with some clinical efficacy in IBD patients and animal models of IBD (Goenka, Kochhar et al., 1996, Kanvinde, Chhonker et al., 2018, Nagar, Ranade et al., 2014, Park, Jang et al., 2019). It is unclear if these effects were due to IL-12 regulation but targeting IL-12, specifically, the IL-12p40 subunit that is shared with IL-23, has also proven beneficial for some IBD patients (Feagan, Sandborn et al., 2016, Moschen et al., 2019, Sands, Sandborn et al., 2019). Therefore, understanding how autophagy or single autophagic proteins regulate proinflammatory cytokines will allow precision in modulating the immune system in chronic inflammatory conditions like IBD. Lastly, targeting these autophagy proteins or their functions could be an alternative to mitigate problems associated with biologics including loss of function, immunogenicity and cost (D'Haens, 2007).

In conclusion, our data support a novel role for Atg5 expression in myeloid cells in regulating intestinal homeostasis. Atg5 expression in myeloid cells controls the IL-12-IFNy pathway that influences the microbiota and limits this pathway during colitis (Supp. Fig. $3 \mathrm{D}$ ). Mechanistically, we show both Atg5 and the cargo receptor NBR1 regulate IL-12 secretion in myeloid cells. Specifically, we propose that NBR1 shuttles IL-12 to LE whereby Atg5 functions to control the $\mathrm{pH}$ of these IL-12 containing vesicles for secretion. A genetic deletion of Atg5 results in dysregulation of IL-12 secretion as well as the accumulation of SLR's such as NBR1 (Kirkin et al., 2009) which could potentially allow for increased accumulation of IL-12 in LE. Consequently, these attributes increase IL-12 secretion. A reduction in IL-12 secretion could be achieved by removing NBR1 or reducing LE/lysosomal pH with Baf. A1 even in the absence of Atg5 expression. Nevertheless, the dysregulation of IL-12 in Atg5 $\Delta$ Mye mice leads to alterations of the microbiota and severe colitis when the intestinal barrier is disrupted. 


\section{MATERIALS AND METHODS}

Animals. The transgenic Atg5 $\Delta$ Mye mice (myeloid specific Atg5 deletion) and Atg5-Wt mice have previously been characterized (Zhao et al., 2008). B6.129S1-//12a $a^{\mathrm{tm} 1 \mathrm{jm} / J}$ (IL-12p35deficient mice) were purchased from JAX (002692) (Mattner et al., 1996) and crossed to Atg5 $\Delta$ Mye mice to generate Atg5 $\Delta$ Mye-IL12KO mice. All mice were genotyped for the presence of Atg5, I/12a or Cre expression by Transnetyx Inc. All experiments were approved by the Institutional Animal Care and Use Committee of the University of New Mexico Health Sciences Center, in accordance with the National Institutes of Health guidelines for use of live animals. The University of New Mexico Health Sciences Center is accredited by the American Association ofor Accreditation of Laboratory Animal Care.

Intestinal inflammation model. For Dextran Sodium Sulfate (DSS)-induced colitis, mice were provided 2.5\% DSS (colitis grade, 30,000 -50,000 MW; MP Biomedicals) in drinking water adlibitum. Reagent used for in vivo treatment as well as sample collection and stimulation are included in Table S1.

Microbiota analysis. Fecal samples from Atg5-Wt, Atg $5 \Delta$ Mye, and Atg $5 \Delta$ Mye-IL-12KO mice were collected fresh in sterile tubes and flash frozen. Microbial communities were determined by sequencing of the 16S rRNA as previously reported (Komesu, Richter et al., 2017) with minor modifications described below. Microbial DNA was isolated from feces using the ZymoBIOMICS DNA Miniprep Kit (Zymo Research) following manufacturer's recommendations. Variable regions $\mathrm{V}-3$ through $\mathrm{V}-4$ of the 16S rRNA gene were amplified by PCR using $100 \mathrm{ng}$ input of DNA for each sample in duplicate using primers 319F- (5'-ACTCCTRCGGGAGGCAGCAG-3') and 806R- (5'-GACAGGACTACHVGGGTATCTAATCC-3') containing Nextera adapter overhangs. A second PCR was performed with Nextera ${ }^{\circledR}$ XT Index Kit v2 Set A (Illumina) to complete the adapter and add a unique sample-specific barcodes. After each PCR, a clean-up with AxyPrep Fragment Select-I magnetic beads (Axygen Biosciences) was completed, and all PCR reactions were run on an Applied Biosystems 2720 Thermal Cycler. Indexed samples were combined to yield duplicate $300 \mathrm{ng}$ pools, followed by the creation and denaturation of a $4 \mathrm{nM}$ library, and paired 250bp sequencing runs were completed on the Illumina MiSeq using v3 sequencing chemistry (Illumina). All reagents and kits are listed in Table S2. 
Microscopy and image analysis. For confocal microscopy, macrophages were plated at 100k cells per well on $18 \mathrm{~mm}$ glass coverslips and stimulated with LPS (500 ng/mL) and IFNy (10 $\mathrm{ng} / \mathrm{mL})$ for 8 hours and treated with BrefA $(10 \mathrm{nM})$ or Baf. $\mathrm{A} 1(10 \mathrm{nM})$ for 2 hours. Cells were then fixed with 4\% PFA followed by a wash with 1x PBS. Blocking buffer contained PBS with $50 \%$ FBS, $2 \%$ BSA and $0.1 \%$ saponin. After a 1 -hour stain in primary antibody, cells were washed with PBS then followed by 1- hour stain in blocking buffer containing secondary antibody. Cells were mounted using ProLong Gold Antifade with DAPI and imaged using the Zeiss LSM 800 Airyscan Confocal microscope with a 63x oil objective lens. Images were processed using Zen Software and Adobe Photoshop (version CC 2019). All primary and secondary antibodies used for confocal staining are listed in Table S3.

Statistical Analysis. Statistical analysis was performed as described in figure legends and graphs generated display mean $( \pm S D)$ and were obtained using Prism software. Microbiome data was sequenced and processed by Illumina's service lab using their inhouse analysis pipeline. Cluster analysis was performed using heatmap3 (Zhao, Guo et al., 2014) package in R. T-test was used to measure specific microbiome species abundance between conditions. Adjust $p$-value $>0.05$ was used as significant threshold. Principle coordinate analysis was conducted in R. Confocal Images Statistical Analysis and Additional Software - Pearson's Correlation Coefficient was acquired from BMM images using Huygens's Deconvolution Scientific Volume Image Software (UNM Fluorescence Microscopy and Cell Imaging shared resource). Quantification figures were also made using Prism, while confocal image figures were constructed using Adobe Illustrator (version CC 2019). All other data were analyzed using one -way ANOVA or two-tailed unpaired Student's t test (Prism).

Online supplemental material. Material and methods for cell and tissue preparation, RTqPCR, flow cytometry, histology, immunoblotting are found in supplemental material.

Author contributions. SDM and SMG performed all analysis with the help from YG, ZERW, JRB, RRG, AJH, JGI and SBB. SDM, ZERW, YG, KCS and DLD contributed to microbiota sequencing and analysis. SMG, JRB and SBB participated in imaging and analysis. JGI, SBB and VD provided reagents and animals. SDM and SMG participated in writing the manuscript. EFC designed the study, analyzed data and wrote the paper. All authors approved the final version of the manuscript. 


\section{Declaration of Competing Interest}

The authors declare no conflict of interest.

\section{Acknowledgments}

Supported in part by the National Center for Research Resources and the National Center for

Advancing Translational Sciences of the National Institutes of Health (NIH) through grant no.

UL1TR001449 (E.F.C.) and in part by NIH grant P20GM121176 (E.F.C.), and the Bioinformatics

Shared Resource at University of New Mexico Comprehensive Cancer Center with grant

P30CA118100 (Y.G.). S.M.G. was supported in part by the Infectious Disease and Inflammation

Program pre-doctoral T32 training grant, NIH/NIAID grant T32AI007538. 


\section{References}

Abdel Fattah E, Bhattacharya A, Herron A, Safdar Z, Eissa NT (2015) Critical role for IL-18 in spontaneous lung inflammation caused by autophagy deficiency. J Immunol 194: 5407-16

Abdi K, Singh NJ (2015) Making many from few: IL-12p40 as a model for the combinatorial assembly of heterodimeric cytokines. Cytokine 76: 53-7

Angelidou I, Chrysanthopoulou A, Mitsios A, Arelaki S, Arampatzioglou A, Kambas K, Ritis D, Tsironidou V, Moschos I, Dalla V, Stakos D, Kouklakis G, Mitroulis I, Ritis K, Skendros P (2018) REDD1/Autophagy Pathway Is Associated with Neutrophil-Driven IL-1beta Inflammatory Response in Active Ulcerative Colitis. J Immunol 200: 3950-3961

Atarashi K, Tanoue T, Shima T, Imaoka A, Kuwahara T, Momose Y, Cheng G, Yamasaki S, Saito T, Ohba Y, Taniguchi T, Takeda K, Hori S, Ivanov, II, Umesaki Y, Itoh K, Honda K (2011) Induction of colonic regulatory $T$ cells by indigenous Clostridium species. Science 331: 337-41

Bader JE, Enos RT, Velazquez KT, Carson MS, Nagarkatti M, Nagarkatti PS, Chatzistamou I, Davis JM, Carson JA, Robinson CM, Murphy EA (2018) Macrophage depletion using clodronate liposomes decreases tumorigenesis and alters gut microbiota in the AOM/DSS mouse model of colon cancer. Am J Physiol Gastrointest Liver Physiol 314: G22-G31

Bain CC, Bravo-Blas A, Scott CL, Perdiguero EG, Geissmann F, Henri S, Malissen B, Osborne LC, Artis D, Mowat AM (2014) Constant replenishment from circulating monocytes maintains the macrophage pool in the intestine of adult mice. Nat Immunol 15: 929-937

Bel S, Pendse M, Wang Y, Li Y, Ruhn KA, Hassell B, Leal T, Winter SE, Xavier RJ, Hooper LV (2017) Paneth cells secrete lysozyme via secretory autophagy during bacterial infection of the intestine. Science 357: 1047-1052

Benjamin JL, Sumpter R, Jr., Levine B, Hooper LV (2013) Intestinal epithelial autophagy is essential for host defense against invasive bacteria. Cell Host Microbe 13: 723-34

Brest $P$, Lapaquette $P$, Souidi M, Lebrigand K, Cesaro A, Vouret-Craviari V, Mari B, Barbry P, Mosnier JF, Hebuterne X, Harel-Bellan A, Mograbi B, Darfeuille-Michaud A, Hofman P (2011) A synonymous variant in IRGM alters a binding site for miR-196 and causes deregulation of IRGM-dependent xenophagy in Crohn's disease. Nat Genet 43: 242-5

Burger E, Araujo A, Lopez-Yglesias A, Rajala MW, Geng L, Levine B, Hooper LV, Burstein E, Yarovinsky F (2018) Loss of Paneth Cell Autophagy Causes Acute Susceptibility to Toxoplasma gondii-Mediated Inflammation. Cell Host Microbe 23: 177-190 e4

Cadwell K, Liu JY, Brown SL, Miyoshi H, Loh J, Lennerz JK, Kishi C, Kc W, Carrero JA, Hunt S, Stone CD, Brunt EM, Xavier RJ, Sleckman BP, Li E, Mizushima N, Stappenbeck TS, Virgin HWt (2008) A key role for autophagy and the autophagy gene Atg16l1 in mouse and human intestinal Paneth cells. Nature 456: 259-63

Cadwell K, Patel KK, Komatsu M, Virgin HWt, Stappenbeck TS (2009) A common role for Atg16L1, Atg5 and Atg7 in small intestinal Paneth cells and Crohn disease. Autophagy 5: 250-2

Carra G, Gerosa F, Trinchieri G (2000) Biosynthesis and posttranslational regulation of human IL-12. J Immunol 164: 4752-61

Castillo EF, Dekonenko A, Arko-Mensah J, Mandell MA, Dupont N, Jiang S, Delgado-Vargas M, Timmins GS, Bhattacharya D, Yang H, Hutt J, Lyons CR, Dobos KM, Deretic V (2012) Autophagy protects against active tuberculosis by suppressing bacterial burden and inflammation. Proc Natl Acad Sci U S A 109:

E3168-76

Chang PV, Hao L, Offermanns S, Medzhitov R (2014) The microbial metabolite butyrate regulates intestinal macrophage function via histone deacetylase inhibition. Proc Natl Acad Sci U S A 111: 2247-52 
Chauhan S, Mandell MA, Deretic V (2015) IRGM governs the core autophagy machinery to conduct antimicrobial defense. Mol Cell 58: 507-21

Chen D, Fan W, Lu Y, Ding X, Chen S, Zhong Q (2012) A mammalian autophagosome maturation mechanism mediated by TECPR1 and the Atg12-Atg5 conjugate. Mol Cell 45: 629-41

Chen L, Sun M, Wu W, Yang W, Huang X, Xiao Y, Ma C, Xu L, Yao S, Liu Z, Cong Y (2019) Microbiota Metabolite Butyrate Differentially Regulates Th1 and Th17 Cells' Differentiation and Function in Induction of Colitis. Inflamm Bowel Dis 25: 1450-1461

Cheng XT, Xie YX, Zhou B, Huang N, Farfel-Becker T, Sheng ZH (2018) Characterization of LAMP1-labeled nondegradative lysosomal and endocytic compartments in neurons. J Cell Biol 217: 3127-3139

Chiaruttini G, Piperno GM, Jouve M, De Nardi F, Larghi P, Peden AA, Baj G, Muller S, Valitutti S, Galli T, Benvenuti F (2016) The SNARE VAMP7 Regulates Exocytic Trafficking of Interleukin-12 in Dendritic Cells. Cell Rep 14: 2624-36

Chung Y, Chang SH, Martinez GJ, Yang XO, Nurieva R, Kang HS, Ma L, Watowich SS, Jetten AM, Tian Q, Dong C (2009) Critical regulation of early Th17 cell differentiation by interleukin-1 signaling. Immunity 30: $576-87$

Claude-Taupin A, Bissa B, Jia J, Gu Y, Deretic V (2018) Role of autophagy in IL-1beta export and release from cells. Semin Cell Dev Biol 83: 36-41

Claude-Taupin A, Jia J, Mudd M, Deretic V (2017) Autophagy's secret life: secretion instead of degradation. Essays Biochem 61: 637-647

Coccia M, Harrison OJ, Schiering C, Asquith MJ, Becher B, Powrie F, Maloy KJ (2012) IL-1beta mediates chronic intestinal inflammation by promoting the accumulation of IL-17A secreting innate lymphoid cells and CD4(+) Th17 cells. J Exp Med 209: 1595-609

Cooper MA, Fehniger TA, Ponnappan A, Mehta V, Wewers MD, Caligiuri MA (2001) Interleukin-1beta costimulates interferon-gamma production by human natural killer cells. Eur J Immunol 31: 792-801 D'Andrea A, Rengaraju M, Valiante NM, Chehimi J, Kubin M, Aste M, Chan SH, Kobayashi M, Young D, Nickbarg E, et al. (1992) Production of natural killer cell stimulatory factor (interleukin 12) by peripheral blood mononuclear cells. J Exp Med 176: 1387-98

D'Haens G (2007) Risks and benefits of biologic therapy for inflammatory bowel diseases. Gut 56: 725-32 Dann SM, Manthey CF, Le C, Miyamoto Y, Gima L, Abrahim A, Cao AT, Hanson EM, Kolls JK, Raz E, Cong $Y$, Eckmann L (2015) IL-17A promotes protective IgA responses and expression of other potential effectors against the lumen-dwelling enteric parasite Giardia. Exp Parasitol 156: 68-78 Dragasevic S, Stankovic B, Sokic-Milutinovic A, Milosavljevic T, Milovanovic T, Lukic S, Drazilov SS, Klaassen K, Kotur N, Pavlovic S, Popovic D (2018) Importance of TLR9-IL23-IL17 axis in inflammatory bowel disease development: Gene expression profiling study. Clin Immunol 197: 86-95

Dunster K, Toh BH, Sentry JW (2002) Early endosomes, late endosomes, and lysosomes display distinct partitioning strategies of inheritance with similarities to Golgi-derived membranes. Eur J Cell Biol 81:

117-24

Dupont N, Jiang S, Pilli M, Ornatowski W, Bhattacharya D, Deretic V (2011) Autophagy-based unconventional secretory pathway for extracellular delivery of IL-1beta. EMBO J 30: 4701-11 Eftychi C, Schwarzer R, Vlantis K, Wachsmuth L, Basic M, Wagle P, Neurath MF, Becker C, Bleich A, Pasparakis M (2019) Temporally Distinct Functions of the Cytokines IL-12 and IL-23 Drive Chronic Colon Inflammation in Response to Intestinal Barrier Impairment. Immunity 51: 367-380 e4

Feagan BG, Sandborn WJ, Gasink C, Jacobstein D, Lang Y, Friedman JR, Blank MA, Johanns J, Gao LL, Miao Y, Adedokun OJ, Sands BE, Hanauer SB, Vermeire S, Targan S, Ghosh S, de Villiers WJ, Colombel JF, Tulassay Z, Seidler U et al. (2016) Ustekinumab as Induction and Maintenance Therapy for Crohn's Disease. N Engl J Med 375: 1946-1960

Fraser J, Simpson J, Fontana R, Kishi-Itakura C, Ktistakis NT, Gammoh N (2019) Targeting of early endosomes by autophagy facilitates EGFR recycling and signalling. EMBO Rep 20: e47734 
Fujino S, Andoh A, Bamba S, Ogawa A, Hata K, Araki Y, Bamba T, Fujiyama Y (2003) Increased expression of interleukin 17 in inflammatory bowel disease. Gut 52: 65-70

Galluzzi L, Baehrecke EH, Ballabio A, Boya P, Bravo-San Pedro JM, Cecconi F, Choi AM, Chu CT, Codogno P, Colombo MI, Cuervo AM, Debnath J, Deretic V, Dikic I, Eskelinen EL, Fimia GM, Fulda S, Gewirtz DA, Green DR, Hansen M et al. (2017) Molecular definitions of autophagy and related processes. EMBO J 36: 1811-1836

Goenka MK, Kochhar R, Tandia B, Mehta SK (1996) Chloroquine for mild to moderately active ulcerative colitis: comparison with sulfasalazine. Am J Gastroenterol 91: 917-21

Guo H, Chitiprolu M, Roncevic L, Javalet C, Hemming FJ, Trung MT, Meng L, Latreille E, Tanese de Souza C, McCulloch D, Baldwin RM, Auer R, Cote J, Russell RC, Sadoul R, Gibbings D (2017) Atg5 Disassociates the V1V0-ATPase to Promote Exosome Production and Tumor Metastasis Independent of Canonical Macroautophagy. Dev Cell 43: 716-730 e7

Hampe J, Franke A, Rosenstiel P, Till A, Teuber M, Huse K, Albrecht M, Mayr G, De La Vega FM, Briggs J, Gunther S, Prescott NJ, Onnie CM, Hasler R, Sipos B, Folsch UR, Lengauer T, Platzer M, Mathew CG, Krawczak M et al. (2007) A genome-wide association scan of nonsynonymous SNPs identifies a susceptibility variant for Crohn disease in ATG16L1. Nat Genet 39: 207-11

Hanada T, Noda NN, Satomi Y, Ichimura Y, Fujioka Y, Takao T, Inagaki F, Ohsumi Y (2007) The Atg12-Atg5 conjugate has a novel E3-like activity for protein lipidation in autophagy. J Biol Chem 282: 37298-302 Harada M, Shakado S, Sakisaka S, Tamaki S, Ohishi M, Sasatomi K, Koga H, Sata M, Tanikawa K (1997) Bafilomycin A1, a specific inhibitor of V-type H+-ATPases, inhibits the acidification of endocytic structures and inhibits horseradish peroxidase uptake in isolated rat sinusoidal endothelial cells. Liver 17: $244-50$

Henckaerts L, Cleynen I, Brinar M, John JM, Van Steen K, Rutgeerts P, Vermeire S (2011) Genetic variation in the autophagy gene ULK1 and risk of Crohn's disease. Inflamm Bowel Dis 17: 1392-7 Homer CR, Richmond AL, Rebert NA, Achkar JP, McDonald C (2010) ATG16L1 and NOD2 interact in an autophagy-dependent antibacterial pathway implicated in Crohn's disease pathogenesis.

Gastroenterology 139: 1630-41, 1641 e1-2

Hueber W, Sands BE, Lewitzky S, Vandemeulebroecke M, Reinisch W, Higgins PD, Wehkamp J, Feagan BG, Yao MD, Karczewski M, Karczewski J, Pezous N, Bek S, Bruin G, Mellgard B, Berger C, Londei M, Bertolino AP, Tougas G, Travis SP et al. (2012) Secukinumab, a human anti-IL-17A monoclonal antibody, for moderate to severe Crohn's disease: unexpected results of a randomised, double-blind placebocontrolled trial. Gut 61: 1693-700

Imhann F, Vich Vila A, Bonder MJ, Fu J, Gevers D, Visschedijk MC, Spekhorst LM, Alberts R, Franke L, van Dullemen HM, Ter Steege RWF, Huttenhower C, Dijkstra G, Xavier RJ, Festen EAM, Wijmenga C, Zhernakova A, Weersma RK (2018) Interplay of host genetics and gut microbiota underlying the onset and clinical presentation of inflammatory bowel disease. Gut 67: 108-119

Inomata M, Into T, Niida S, Murakami Y (2013) Atg5 regulates formation of MyD88 condensed structures and MyD88-dependent signal transduction. Biochem Biophys Res Commun 437: 509-14

Ito R, Shin-Ya M, Kishida T, Urano A, Takada R, Sakagami J, Imanishi J, Kita M, Ueda Y, Iwakura Y, Kataoka $\mathrm{K}$, Okanoue T, Mazda O (2006) Interferon-gamma is causatively involved in experimental inflammatory bowel disease in mice. Clin Exp Immunol 146: 330-8

Ivanov, II, Atarashi K, Manel N, Brodie EL, Shima T, Karaoz U, Wei D, Goldfarb KC, Santee CA, Lynch SV, Tanoue T, Imaoka A, Itoh K, Takeda K, Umesaki Y, Honda K, Littman DR (2009) Induction of intestinal Th17 cells by segmented filamentous bacteria. Cell 139: 485-98

Ivanov, II, Frutos Rde L, Manel N, Yoshinaga K, Rifkin DB, Sartor RB, Finlay BB, Littman DR (2008) Specific microbiota direct the differentiation of IL-17-producing T-helper cells in the mucosa of the small intestine. Cell Host Microbe 4: 337-49 
Jiang S, Dupont N, Castillo EF, Deretic V (2013) Secretory versus degradative autophagy: unconventional secretion of inflammatory mediators. J Innate Immun 5: 471-9

Jiang W, Su J, Zhang X, Cheng X, Zhou J, Shi R, Zhang H (2014) Elevated levels of Th17 cells and Th17related cytokines are associated with disease activity in patients with inflammatory bowel disease. Inflamm Res 63: 943-50

Kanai T, Mikami Y, Sujino T, Hisamatsu T, Hibi T (2012) RORgammat-dependent IL-17A-producing cells in the pathogenesis of intestinal inflammation. Mucosal Immunol 5: 240-7

Kang B, Alvarado L, Kim T, Lehmann ML, Cho H, He J, Li P, Kim BH, Larochelle A, Kelsall BL (2020)

Commensal microbiota drive the functional diversification of colon macrophages. Mucosal Immunol 13:

216-229

Kanvinde S, Chhonker YS, Ahmad R, Yu F, Sleightholm R, Tang W, Jaramillo L, Chen Y, Sheinin Y, Li J, Murry DJ, Singh AB, Oupicky D (2018) Pharmacokinetics and efficacy of orally administered polymeric chloroquine as macromolecular drug in the treatment of inflammatory bowel disease. Acta Biomater 82: 158-170

Kimura T, Jia J, Kumar S, Choi SW, Gu Y, Mudd M, Dupont N, Jiang S, Peters R, Farzam F, Jain A, Lidke KA, Adams CM, Johansen T, Deretic V (2017) Dedicated SNAREs and specialized TRIM cargo receptors mediate secretory autophagy. EMBO J 36: 42-60

Kirkin V, Lamark T, Sou YS, Bjorkoy G, Nunn JL, Bruun JA, Shvets E, McEwan DG, Clausen TH, Wild P, Bilusic I, Theurillat JP, Overvatn A, Ishii T, Elazar Z, Komatsu M, Dikic I, Johansen T (2009) A role for NBR1 in autophagosomal degradation of ubiquitinated substrates. Mol Cell 33: 505-16

Komesu YM, Richter HE, Dinwiddie DL, Siddiqui NY, Sung VW, Lukacz ES, Ridgeway B, Arya LA, Zyczynski HM, Rogers RG, Gantz M (2017) Methodology for a vaginal and urinary microbiome study in women with mixed urinary incontinence. Int Urogynecol J 28: 711-720

Kozakov D, Hall DR, Xia B, Porter KA, Padhorny D, Yueh C, Beglov D, Vajda S (2017) The ClusPro web server for protein-protein docking. Nat Protoc 12: 255-278

Kumar P, Monin L, Castillo P, Elsegeiny W, Horne W, Eddens T, Vikram A, Good M, Schoenborn AA, Bibby K, Montelaro RC, Metzger DW, Gulati AS, Kolls JK (2016) Intestinal Interleukin-17 Receptor Signaling Mediates Reciprocal Control of the Gut Microbiota and Autoimmune Inflammation. Immunity 44: 659671

Lahiri A, Hedl M, Abraham C (2015) MTMR3 risk allele enhances innate receptor-induced signaling and cytokines by decreasing autophagy and increasing caspase-1 activation. Proc Natl Acad Sci U S A 112: 10461-6

Lassen KG, Xavier RJ (2018) Mechanisms and function of autophagy in intestinal disease. Autophagy 14: 216-220

Lavoie S, Conway KL, Lassen KG, Jijon HB, Pan H, Chun E, Michaud M, Lang JK, Gallini Comeau CA, Dreyfuss JM, Glickman JN, Vlamakis H, Ananthakrishnan A, Kostic A, Garrett WS, Xavier RJ (2019) The Crohn's disease polymorphism, ATG16L1 T300A, alters the gut microbiota and enhances the local Th1/Th17 response. Elife 8

Lee HK, Mattei LM, Steinberg BE, Alberts P, Lee YH, Chervonsky A, Mizushima N, Grinstein S, Iwasaki A (2010) In vivo requirement for Atg5 in antigen presentation by dendritic cells. Immunity 32: 227-39 Lee HY, Kim J, Quan W, Lee JC, Kim MS, Kim SH, Bae JW, Hur KY, Lee MS (2016a) Autophagy deficiency in myeloid cells increases susceptibility to obesity-induced diabetes and experimental colitis. Autophagy 12: $1390-403$

Lee JP, Foote A, Fan H, Peral de Castro C, Lang T, Jones SA, Gavrilescu N, Mills KH, Leech M, Morand EF, Harris J (2016b) Loss of autophagy enhances MIF/macrophage migration inhibitory factor release by macrophages. Autophagy 12: 907-16

Levine B, Kroemer G (2019) Biological Functions of Autophagy Genes: A Disease Perspective. Cell 176: 11-42 
Liu Z, Yadav PK, Xu X, Su J, Chen C, Tang M, Lin H, Yu J, Qian J, Yang PC, Wang X (2011) The increased expression of IL-23 in inflammatory bowel disease promotes intraepithelial and lamina propria lymphocyte inflammatory responses and cytotoxicity. J Leukoc Biol 89: 597-606 Macedo C, Turnquist HR, Castillo-Rama M, Zahorchak AF, Shapiro R, Thomson AW, Metes D (2013) Rapamycin augments human DC IL-12p70 and IL-27 secretion to promote allogeneic Type 1 polarization modulated by NK cells. Am J Transplant 13: 2322-33

Manichanh C, Borruel N, Casellas F, Guarner F (2012) The gut microbiota in IBD. Nat Rev Gastroenterol Hepatol 9: 599-608

Manichanh C, Rigottier-Gois L, Bonnaud E, Gloux K, Pelletier E, Frangeul L, Nalin R, Jarrin C, Chardon P, Marteau P, Roca J, Dore J (2006) Reduced diversity of faecal microbiota in Crohn's disease revealed by a metagenomic approach. Gut 55: 205-11

Mao L, Kitani A, Strober W, Fuss IJ (2018) The Role of NLRP3 and IL-1beta in the Pathogenesis of Inflammatory Bowel Disease. Front Immunol 9: 2566

Mardakheh FK, Yekezare M, Machesky LM, Heath JK (2009) Spred2 interaction with the late endosomal protein NBR1 down-regulates fibroblast growth factor receptor signaling. J Cell Biol 187: 265-77 Matsuzawa-Ishimoto Y, Shono Y, Gomez LE, Hubbard-Lucey VM, Cammer M, Neil J, Dewan MZ, Lieberman SR, Lazrak A, Marinis JM, Beal A, Harris PA, Bertin J, Liu C, Ding Y, van den Brink MRM, Cadwell K (2017) Autophagy protein ATG16L1 prevents necroptosis in the intestinal epithelium. J Exp Med 214: 3687-3705

Mattner F, Magram J, Ferrante J, Launois P, Di Padova K, Behin R, Gately MK, Louis JA, Alber G (1996) Genetically resistant mice lacking interleukin-12 are susceptible to infection with Leishmania major and mount a polarized Th2 cell response. Eur J Immunol 26: 1553-9

McCarroll SA, Huett A, Kuballa P, Chilewski SD, Landry A, Goyette P, Zody MC, Hall JL, Brant SR, Cho JH, Duerr RH, Silverberg MS, Taylor KD, Rioux JD, Altshuler D, Daly MJ, Xavier RJ (2008) Deletion polymorphism upstream of IRGM associated with altered IRGM expression and Crohn's disease. Nat Genet 40: 1107-12

McGeachy MJ, Chen Y, Tato CM, Laurence A, Joyce-Shaikh B, Blumenschein WM, McClanahan TK, O'Shea JJ, Cua DJ (2009) The interleukin 23 receptor is essential for the terminal differentiation of interleukin 17-producing effector T helper cells in vivo. Nat Immunol 10: 314-24

Menghini P, Corridoni D, Butto LF, Osme A, Shivaswamy S, Lam M, Bamias G, Pizarro TT, RodriguezPalacios A, Dinarello CA, Cominelli F (2019) Neutralization of IL-1alpha ameliorates Crohn's disease-like ileitis by functional alterations of the gut microbiome. Proc Natl Acad Sci U S A

Merkley SD, Chock CJ, Yang XO, Harris J, Castillo EF (2018) Modulating T Cell Responses via Autophagy: The Intrinsic Influence Controlling the Function of Both Antigen-Presenting Cells and T Cells. Front Immunol 9: 2914

Mizushima N, Noda T, Yoshimori T, Tanaka Y, Ishii T, George MD, Klionsky DJ, Ohsumi M, Ohsumi Y (1998) A protein conjugation system essential for autophagy. Nature 395: 395-8

Mortha A, Chudnovskiy A, Hashimoto D, Bogunovic M, Spencer SP, Belkaid Y, Merad M (2014) Microbiota-dependent crosstalk between macrophages and ILC3 promotes intestinal homeostasis. Science 343: 1249288

Moschen AR, Tilg H, Raine T (2019) IL-12, IL-23 and IL-17 in IBD: immunobiology and therapeutic targeting. Nat Rev Gastroenterol Hepatol 16: 185-196

Murai H, Okazaki S, Hayashi H, Kawakita A, Hosoki K, Yasutomi M, Sur S, Ohshima Y (2015) Alternaria extract activates autophagy that induces IL-18 release from airway epithelial cells. Biochem Biophys Res Commun 464: 969-974

Nagar J, Ranade S, Kamath V, Singh S, Karunanithi P, Subramani S, Venkatesh K, Srivastava R, Dudhgaonkar S, Vikramadithyan RK (2014) Therapeutic potential of chloroquine in a murine model of inflammatory bowel disease. Int Immunopharmacol 21: 328-35 
Ndoye A, Budina-Kolomets A, Kugel CH, 3rd, Webster MR, Kaur A, Behera R, Rebecca VW, Li L, Brafford PA, Liu Q, Gopal YNV, Davies MA, Mills GB, Xu X, Wu H, Herlyn M, Nicastri MC, Winkler JD, Soengas MS, Amaravadi RK et al. (2017) ATG5 Mediates a Positive Feedback Loop between Wnt Signaling and Autophagy in Melanoma. Cancer Res 77: 5873-5885 Nguyen HT, Dalmasso G, Muller S, Carriere J, Seibold F, Darfeuille-Michaud A (2014) Crohn's diseaseassociated adherent invasive Escherichia coli modulate levels of microRNAs in intestinal epithelial cells to reduce autophagy. Gastroenterology 146: 508-19 Ni J, Wu GD, Albenberg L, Tomov VT (2017) Gut microbiota and IBD: causation or correlation? Nat Rev Gastroenterol Hepatol 14: 573-584

Niess JH, Brand S, Gu X, Landsman L, Jung S, McCormick BA, Vyas JM, Boes M, Ploegh HL, Fox JG, Littman DR, Reinecker HC (2005) CX3CR1-mediated dendritic cell access to the intestinal lumen and bacterial clearance. Science 307: 254-8

Nighot PK, Hu CA, Ma TY (2015) Autophagy enhances intestinal epithelial tight junction barrier function by targeting claudin-2 protein degradation. J Biol Chem 290: 7234-46

Noda NN, Fujioka Y, Hanada T, Ohsumi Y, Inagaki F (2013) Structure of the Atg12-Atg5 conjugate reveals a platform for stimulating Atg8-PE conjugation. EMBO Rep 14: 206-11

Nunes NS, Kim S, Sundby M, Chandran P, Burks SR, Paz AH, Frank JA (2018) Temporal clinical, proteomic, histological and cellular immune responses of dextran sulfate sodium-induced acute colitis. World J Gastroenterol 24: 4341-4355

Ogawa A, Andoh A, Araki Y, Bamba T, Fujiyama Y (2004) Neutralization of interleukin-17 aggravates dextran sulfate sodium-induced colitis in mice. Clin Immunol 110: 55-62

Ohtani M, Nagai S, Kondo S, Mizuno S, Nakamura K, Tanabe M, Takeuchi T, Matsuda S, Koyasu S (2008) Mammalian target of rapamycin and glycogen synthase kinase 3 differentially regulate lipopolysaccharide-induced interleukin-12 production in dendritic cells. Blood 112: 635-43 Park TY, Jang Y, Kim W, Shin J, Toh HT, Kim CH, Yoon HS, Leblanc P, Kim KS (2019) Chloroquine modulates inflammatory autoimmune responses through Nurr1 in autoimmune diseases. Sci Rep 9: 15559

Patel KK, Miyoshi H, Beatty WL, Head RD, Malvin NP, Cadwell K, Guan JL, Saitoh T, Akira S, Seglen PO, Dinauer MC, Virgin HW, Stappenbeck TS (2013) Autophagy proteins control goblet cell function by potentiating reactive oxygen species production. EMBO J 32: 3130-44

Peng J, Zhang R, Cui Y, Liu H, Zhao X, Huang L, Hu M, Yuan X, Ma B, Ma X, Takashi U, Masaaki K, Liang X, Yu L (2014) Atg5 regulates late endosome and lysosome biogenesis. Sci China Life Sci 57: 59-68

Peral de Castro C, Jones SA, Ni Cheallaigh C, Hearnden CA, Williams L, Winter J, Lavelle EC, Mills KH, Harris J (2012) Autophagy regulates IL-23 secretion and innate T cell responses through effects on IL-1 secretion. J Immunol 189: 4144-53

Perussia B, Chan SH, D'Andrea A, Tsuji K, Santoli D, Pospisil M, Young D, Wolf SF, Trinchieri G (1992) Natural killer (NK) cell stimulatory factor or IL-12 has differential effects on the proliferation of TCRalpha beta+, TCR-gamma delta+ T lymphocytes, and NK cells. J Immunol 149: 3495-502

Reed M, Morris SH, Owczarczyk AB, Lukacs NW (2015) Deficiency of autophagy protein Map1-LC3b mediates IL-17-dependent lung pathology during respiratory viral infection via ER stress-associated IL-1. Mucosal Immunol 8: 1118-30

Reitberger S, Haimerl P, Aschenbrenner I, Esser-von Bieren J, Feige MJ (2017) Assembly-induced folding regulates interleukin 12 biogenesis and secretion. J Biol Chem 292: 8073-8081

Rescigno M, Urbano M, Valzasina B, Francolini M, Rotta G, Bonasio R, Granucci F, Kraehenbuhl JP, Ricciardi-Castagnoli P (2001) Dendritic cells express tight junction proteins and penetrate gut epithelial monolayers to sample bacteria. Nat Immunol 2: 361-7

Rioux JD, Xavier RJ, Taylor KD, Silverberg MS, Goyette P, Huett A, Green T, Kuballa P, Barmada MM, Datta LW, Shugart YY, Griffiths AM, Targan SR, Ippoliti AF, Bernard EJ, Mei L, Nicolae DL, Regueiro M, 
Schumm LP, Steinhart AH et al. (2007) Genome-wide association study identifies new susceptibility loci for Crohn disease and implicates autophagy in disease pathogenesis. Nat Genet 39: 596-604

Roberts RL, Gearry RB, Hollis-Moffatt JE, Miller AL, Reid J, Abkevich V, Timms KM, Gutin A, Lanchbury JS, Merriman TR, Barclay ML, Kennedy MA (2007) IL23R R381Q and ATG16L1 T300A are strongly associated with Crohn's disease in a study of New Zealand Caucasians with inflammatory bowel disease. Am J Gastroenterol 102: 2754-61

Said A, Bock S, Lajqi T, Muller G, Weindl G (2014) Chloroquine promotes IL-17 production by CD4+ T cells via p38-dependent IL-23 release by monocyte-derived Langerhans-like cells. J Immunol 193: 6135-43 Saitoh T, Fujita N, Jang MH, Uematsu S, Yang BG, Satoh T, Omori H, Noda T, Yamamoto N, Komatsu M, Tanaka K, Kawai T, Tsujimura T, Takeuchi O, Yoshimori T, Akira S (2008) Loss of the autophagy protein Atg16L1 enhances endotoxin-induced IL-1beta production. Nature 456: 264-8 Sakoh-Nakatogawa M, Matoba K, Asai E, Kirisako H, Ishii J, Noda NN, Inagaki F, Nakatogawa H, Ohsumi Y (2013) Atg12-Atg5 conjugate enhances E2 activity of Atg3 by rearranging its catalytic site. Nat Struct Mol Biol 20: 433-9

Sands BE, Sandborn WJ, Panaccione R, O'Brien CD, Zhang H, Johanns J, Adedokun OJ, Li K, PeyrinBiroulet L, Van Assche G, Danese S, Targan S, Abreu MT, Hisamatsu T, Szapary P, Marano C, Group US (2019) Ustekinumab as Induction and Maintenance Therapy for Ulcerative Colitis. N Engl J Med 381: 1201-1214

Schirmer M, Garner A, Vlamakis H, Xavier RJ (2019) Microbial genes and pathways in inflammatory bowel disease. Nat Rev Microbiol 17: 497-511 Seksik P (2010) [Gut microbiota and IBD]. Gastroenterol Clin Biol 34 Suppl 1: S44-51

Shouval DS, Biswas A, Kang YH, Griffith AE, Konnikova L, Mascanfroni ID, Redhu NS, Frei SM, Field M, Doty AL, Goldsmith JD, Bhan AK, Loizides A, Weiss B, Yerushalmi B, Yanagi T, Lui X, Quintana FJ, Muise AM, Klein C et al. (2016) Interleukin 1beta Mediates Intestinal Inflammation in Mice and Patients With Interleukin 10 Receptor Deficiency. Gastroenterology 151: 1100-1104

Simon HU, Yousefi S, Schmid I, Friis R (2014) ATG5 can regulate p53 expression and activation. Cell Death Dis 5: e1339

Singh N, Gurav A, Sivaprakasam S, Brady E, Padia R, Shi H, Thangaraju M, Prasad PD, Manicassamy S, Munn DH, Lee JR, Offermanns S, Ganapathy V (2014) Activation of Gpr109a, receptor for niacin and the commensal metabolite butyrate, suppresses colonic inflammation and carcinogenesis. Immunity 40:

128-39

Singh SB, Davis AS, Taylor GA, Deretic V (2006) Human IRGM induces autophagy to eliminate intracellular mycobacteria. Science 313: 1438-41

Sun M, Wu W, Chen L, Yang W, Huang X, Ma C, Chen F, Xiao Y, Zhao Y, Ma C, Yao S, Carpio VH, Dann SM, Zhao Q, Liu Z, Cong Y (2018) Microbiota-derived short-chain fatty acids promote Th1 cell IL-10 production to maintain intestinal homeostasis. Nat Commun 9: 3555

Targan SR, Feagan B, Vermeire S, Panaccione R, Melmed GY, Landers C, Li D, Russell C, Newmark R, Zhang N, Chon Y, Hsu YH, Lin SL, Klekotka P (2016) A Randomized, Double-Blind, Placebo-Controlled Phase 2 Study of Brodalumab in Patients With Moderate-to-Severe Crohn's Disease. Am J Gastroenterol 111: 1599-1607

Tominaga K, Yoshimoto T, Torigoe K, Kurimoto M, Matsui K, Hada T, Okamura H, Nakanishi K (2000) IL12 synergizes with IL-18 or IL-1beta for IFN-gamma production from human T cells. Int Immunol 12: 15160

Trinchieri G, Wysocka M, D'Andrea A, Rengaraju M, Aste-Amezaga M, Kubin M, Valiante NM, Chehimi J (1992) Natural killer cell stimulatory factor (NKSF) or interleukin-12 is a key regulator of immune response and inflammation. Prog Growth Factor Res 4: 355-68

Vallon-Eberhard A, Landsman L, Yogev N, Verrier B, Jung S (2006) Transepithelial pathogen uptake into the small intestinal lamina propria. J Immunol 176: 2465-9 
Watson RO, Manzanillo PS, Cox JS (2012) Extracellular M. tuberculosis DNA targets bacteria for autophagy by activating the host DNA-sensing pathway. Cell 150: 803-15

Willing BP, Dicksved J, Halfvarson J, Andersson AF, Lucio M, Zheng Z, Jarnerot G, Tysk C, Jansson JK, Engstrand $L$ (2010) A pyrosequencing study in twins shows that gastrointestinal microbial profiles vary with inflammatory bowel disease phenotypes. Gastroenterology 139: 1844-1854 e1

Wong M, Ganapathy AS, Suchanec E, Laidler L, Ma T, Nighot P (2019) Intestinal epithelial tight junction barrier regulation by autophagy-related protein ATG6/beclin 1. Am J Physiol Cell Physiol 316: C753-C765 Wu Y, Wang Y, Zou H, Wang B, Sun Q, Fu A, Wang Y, Wang Y, Xu X, Li W (2017) Probiotic Bacillus amyloliquefaciens SC06 Induces Autophagy to Protect against Pathogens in Macrophages. Front Microbiol 8: 469

Yamazaki K, Onouchi Y, Takazoe M, Kubo M, Nakamura Y, Hata A (2007) Association analysis of genetic variants in IL23R, ATG16L1 and 5p13.1 loci with Crohn's disease in Japanese patients. J Hum Genet 52: 575-583

Yang XO, Chang SH, Park H, Nurieva R, Shah B, Acero L, Wang YH, Schluns KS, Broaddus RR, Zhu Z, Dong $C$ (2008) Regulation of inflammatory responses by IL-17F. J Exp Med 205: 1063-75

Ye X, Zhou XJ, Zhang H (2018) Exploring the Role of Autophagy-Related Gene 5 (ATG5) Yields Important Insights Into Autophagy in Autoimmune/Autoinflammatory Diseases. Front Immunol 9: 2334

Yoshimori T, Yamamoto A, Moriyama Y, Futai M, Tashiro Y (1991) Bafilomycin A1, a specific inhibitor of vacuolar-type $\mathrm{H}(+)$-ATPase, inhibits acidification and protein degradation in lysosomes of cultured cells. $J$ Biol Chem 266: 17707-12

Yousefi S, Perozzo R, Schmid I, Ziemiecki A, Schaffner T, Scapozza L, Brunner T, Simon HU (2006) Calpainmediated cleavage of Atg5 switches autophagy to apoptosis. Nat Cell Biol 8: 1124-32

Zhang $\mathrm{H}$, Zheng L, McGovern DP, Hamill AM, Ichikawa R, Kanazawa Y, Luu J, Kumagai K, Cilluffo M, Fukata M, Targan SR, Underhill DM, Zhang X, Shih DQ (2017) Myeloid ATG16L1 Facilitates Host-Bacteria Interactions in Maintaining Intestinal Homeostasis. J Immunol 198: 2133-2146

Zhang M, Kenny SJ, Ge L, Xu K, Schekman R (2015) Translocation of interleukin-1beta into a vesicle intermediate in autophagy-mediated secretion. Elife 4

Zhao S, Guo Y, Sheng Q, Shyr Y (2014) Advanced heat map and clustering analysis using heatmap3.

Biomed Res Int 2014: 986048

Zhao Z, Fux B, Goodwin M, Dunay IR, Strong D, Miller BC, Cadwell K, Delgado MA, Ponpuak M, Green KG, Schmidt RE, Mizushima N, Deretic V, Sibley LD, Virgin HW (2008) Autophagosome-independent essential function for the autophagy protein Atg5 in cellular immunity to intracellular pathogens. Cell Host Microbe 4: 458-69 
bioRxiv preprint doi: https://doi.org/10.1101/2020.12 07.414227· this version posted December 7,2020. The copyright holder for this preprint (which was not certified by peer review) is the author/funder, who has granted bioRxiv a license to display the preprint in perpetuity. It is made available under aCC-BY-NC-ND 4.0 International license.

Non-autophagy role of Atg5 and NBR1 in unconventional secretion of IL-12 prevents gut dysbiosis and inflammation

Merkley et al.,

Contents: Figures 1-5 and figure legends. 
bioRxiv preprint doi: https://doi.org/10.1101/2020.12.07.414227; this version posted December 7, 2020. The copyright holder for this preprint (which was not certified by peer review) is the author/funder, who has granted bioRxiv a license to display the preprint in perpetuity. It is made available under aCC-BY-NC-ND 4.0 International license.

\section{Figure 1}

A Microbiota composition

(\% of total population)
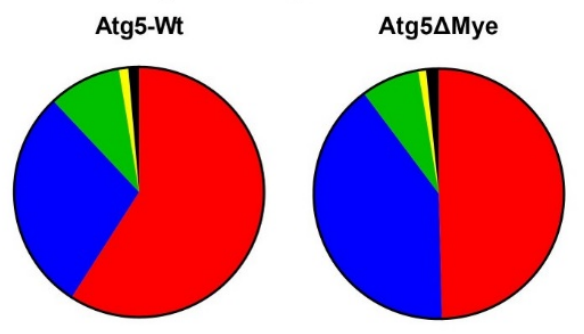

- Firmicutes

$\square$ Actinobacteria

$\square$ Proteobacteria

F
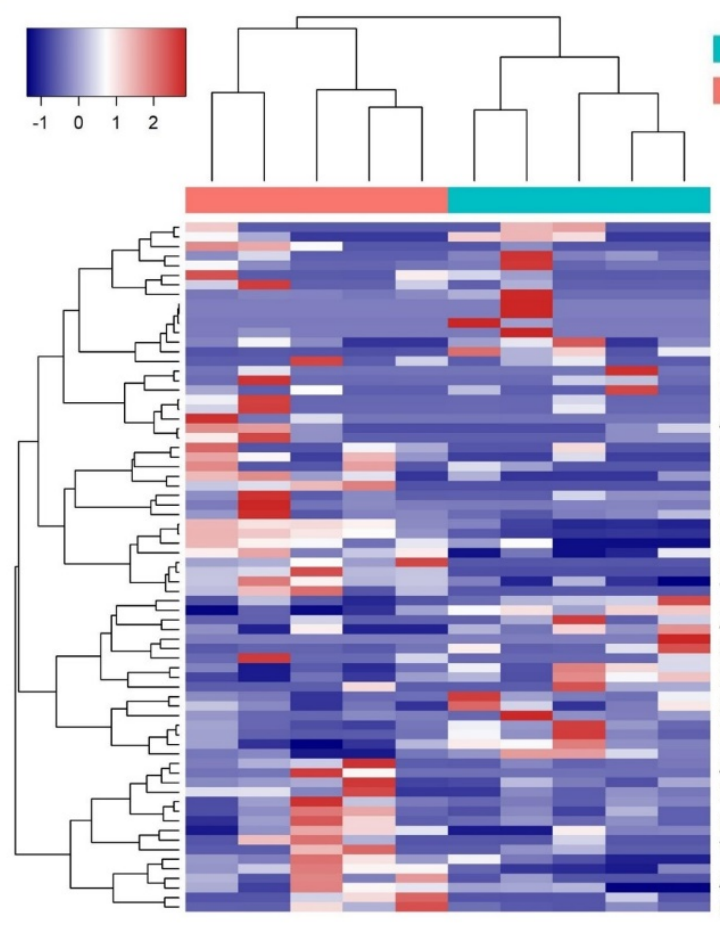

B

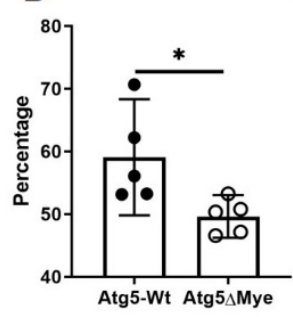

D

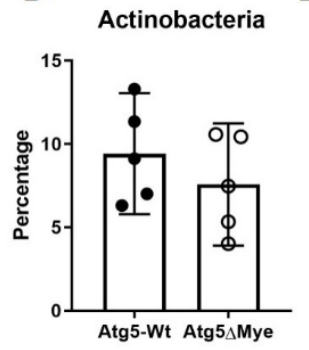

Sporacetigenium Phaeospirillum Pseudomonas Listeria

Rhodanobacter Mangroviflexus Anaerobranca Marininema Legionella Helicobacter Romboutsia Intestinibacter Tepidibacter Zhongshania Salinithrix Faecalitalea Sphingobacterium Holdemanella Acetitomaculum Ruminococcus Gp14

Youngiibacter Anaerorhabdus Olsenella

G

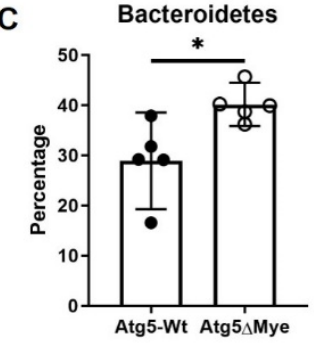

E

Proteobacteria

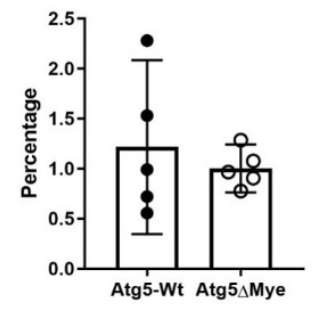

\section{Microbiota composition}

(16S profiling)

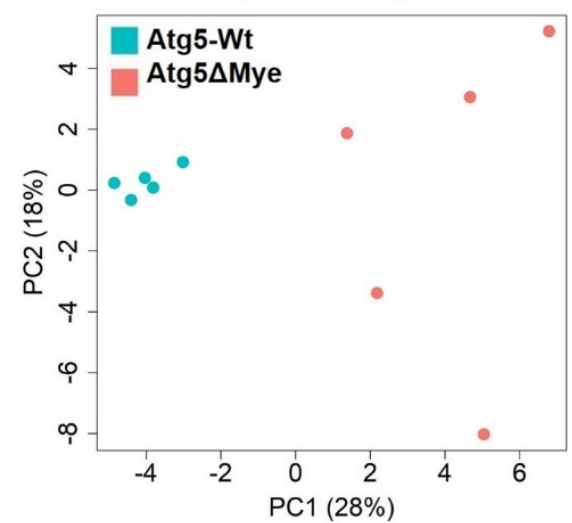


Figure 2

A

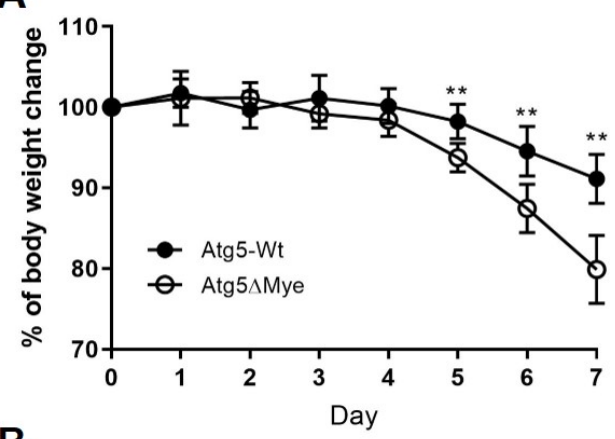

B

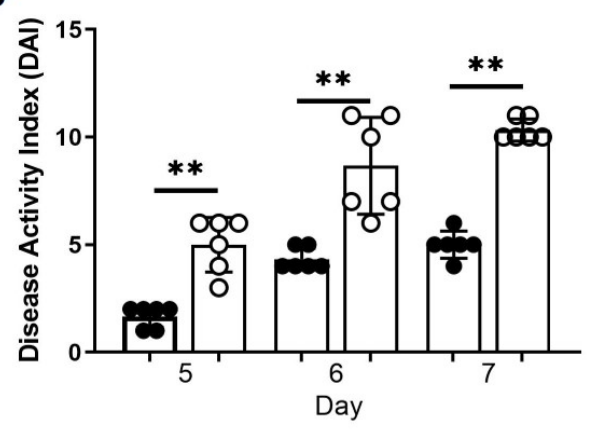

C

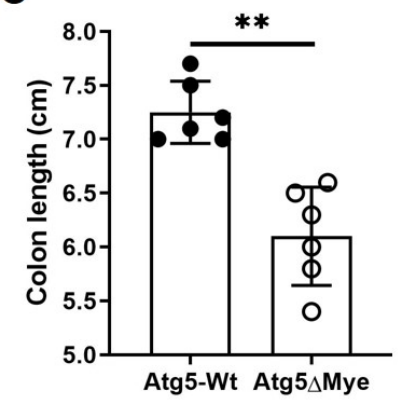

E

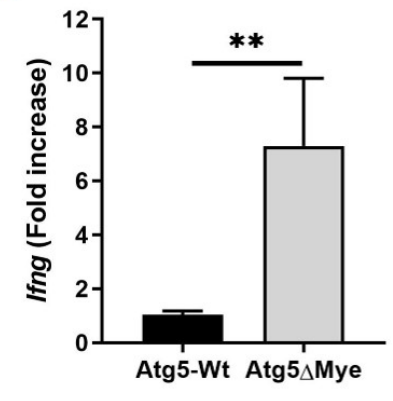

D

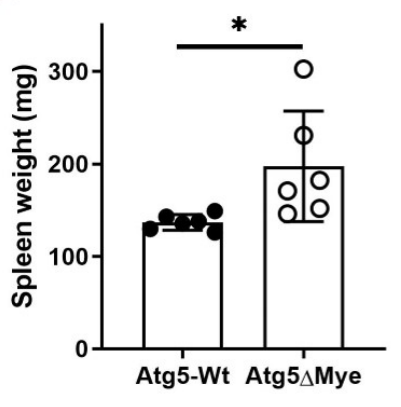

$\mathbf{F}$

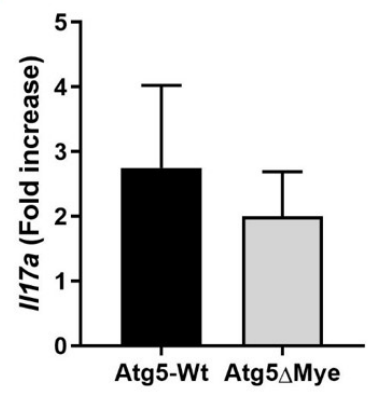

G

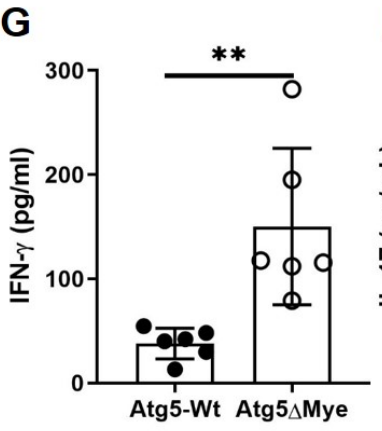

H

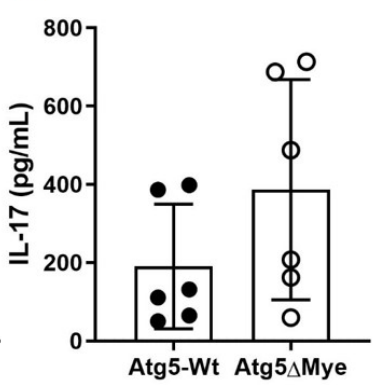

I

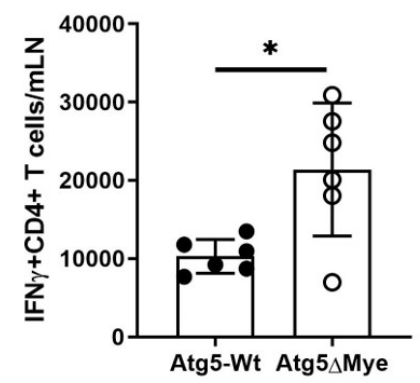

J

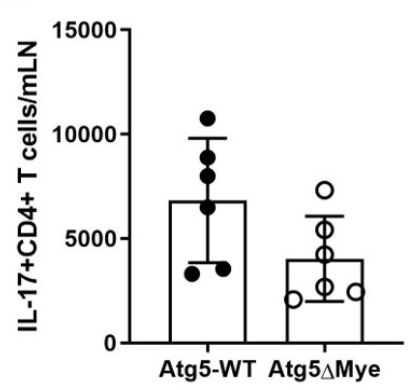


Figure 3
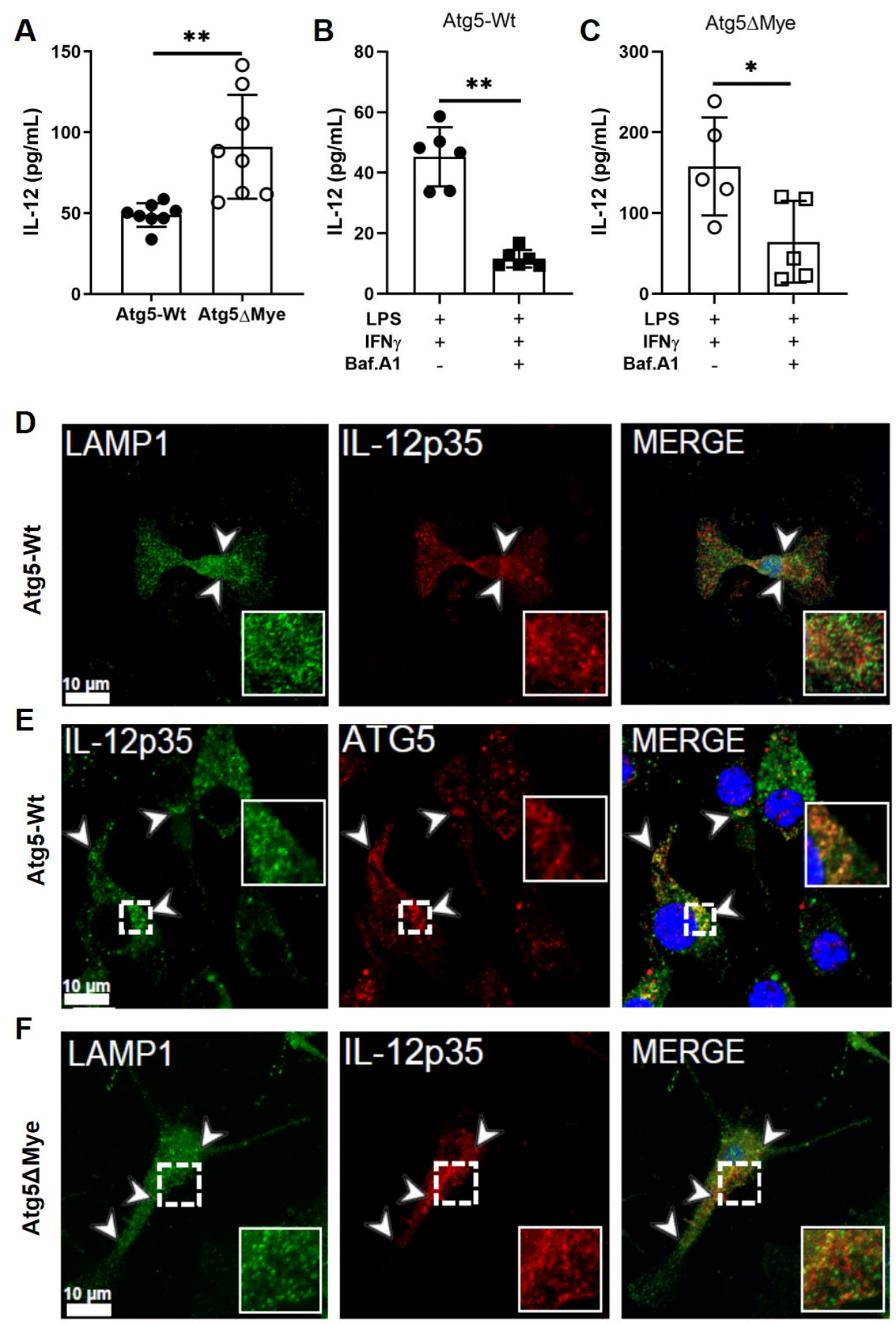
Figure 4
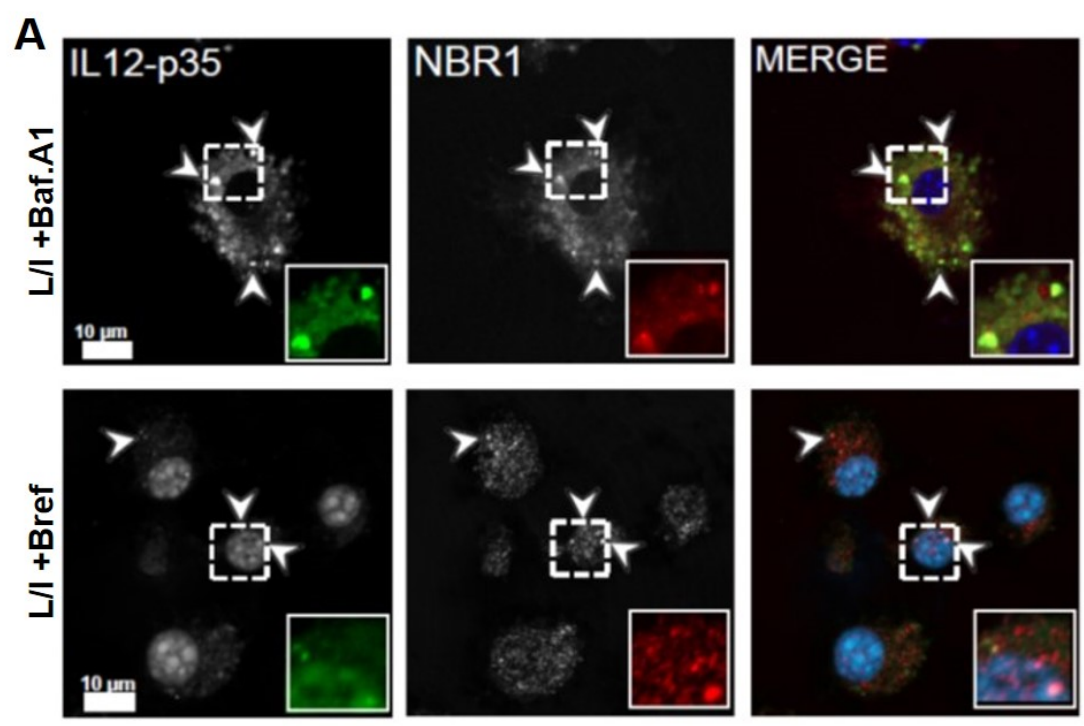

B

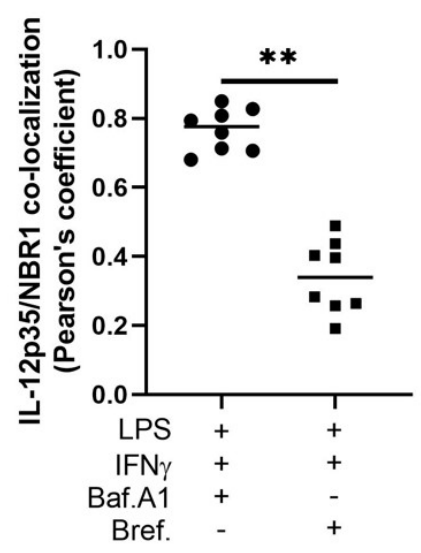

C

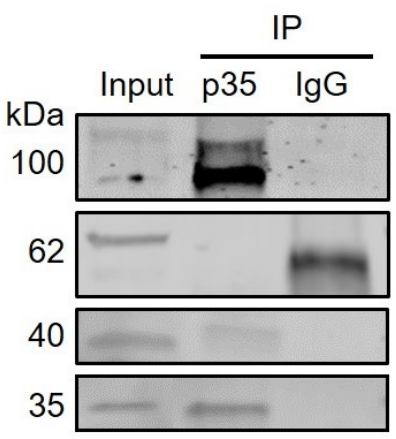

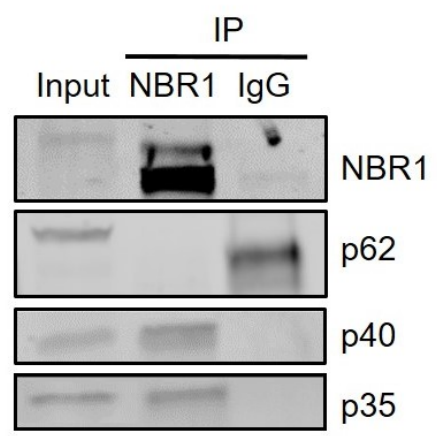

F

\begin{tabular}{|c|c|c|c|c|}
\hline Receptor Ligand & Cluster size & Representative & Weighted Score \\
\hline \multirow{4}{*}{ 1F45 } & 1WJ6 & 120 & Center & -489.9 \\
\cline { 3 - 5 } & & & Lowest Energy & -557.1 \\
\cline { 2 - 5 } & 2L8J & 66 & Center & -717.9 \\
\cline { 4 - 5 } & & Lowest Energy & -890.6 \\
\hline \multirow{4}{*}{ 2MGW } & 213 & Center & -625.5 \\
\cline { 3 - 5 } & & Lowest Energy & -846.0 \\
\hline \multirow{2}{*}{ 2MJ5 } & 97 & Center & -667.0 \\
\cline { 3 - 5 } & & Lowest Energy & -783.6 \\
\hline
\end{tabular}

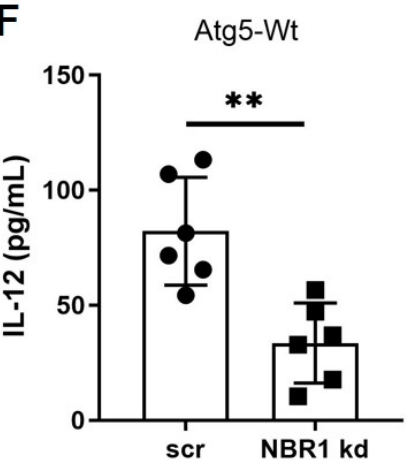

D 1F45:1WJ6 1F45:2L8J

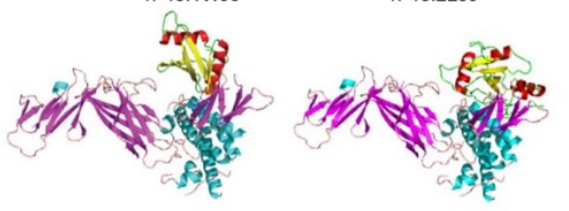

1F45:2MGW

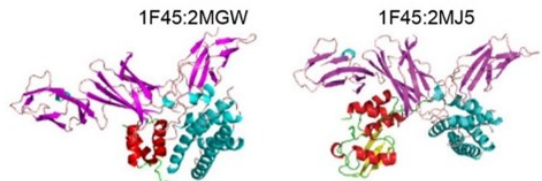

G

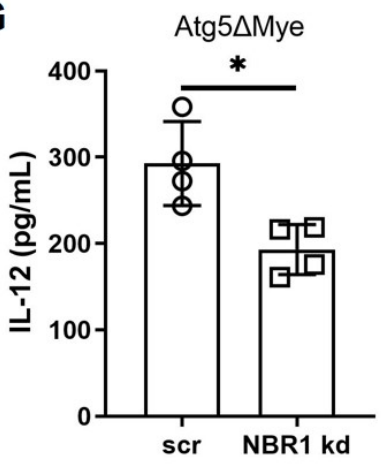


bioRxiv preprint doi: https://doi.org/10.1101/2020.12.07.414227; this version posted December 7, 2020. The copyright holder for this preprint (which was not certified by peer review) is the author/funder, who has granted bioRxiv a license to display the preprint in perpetuity. It is made available under aCC-BY-NC-ND 4.0 International license.

\section{Figure 5}

A

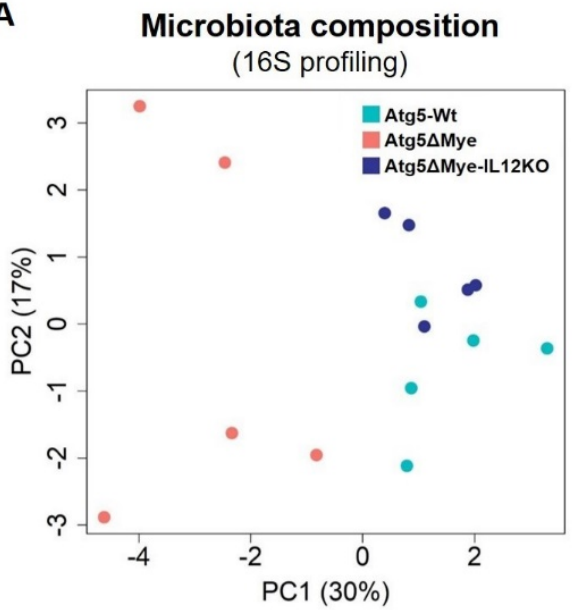

C

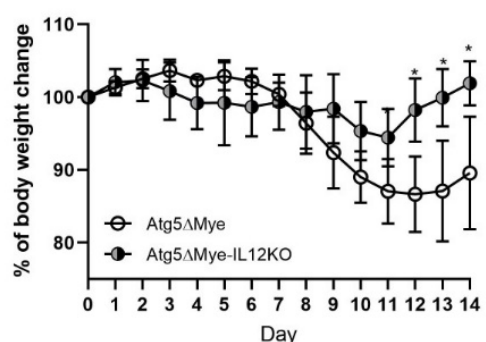

B

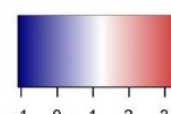

西
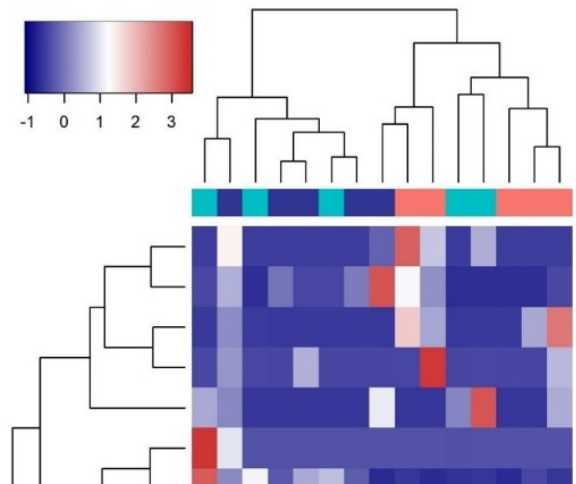

Peptococcus

Anaerofustis

Tepidibacter

Anaerobranca

Zhongshania

Pectinatus

Salinithrix

Insolitispirillum

Anaerorhabdus

Erysipelotrichaceae incertae

Youngiibacter

Mesoplasma

Clostridium XI

Romboutsia

Fonticella

Paenibacillus

Pseudomonas

Sporacetigenium
D

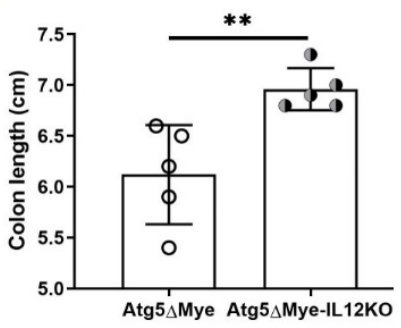

$E$

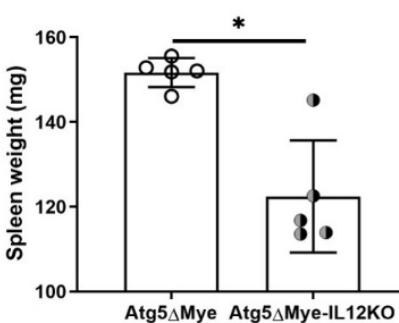

F

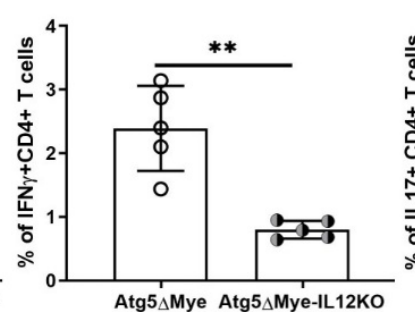

G

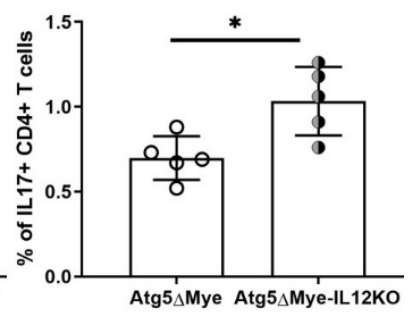




\section{Figure legends}

Figure 1. Alterations in the composition of the colonic microbial community in mice with a selective Atg5-deficiency in myeloid cells. Bacterial composition as assessed by 16S rRNA sequencing of DNA extracted from freshly collected stool of Atg5-Wt and Atg5 $\Delta$ Mye mice $(n=5$ per group). (A) Pie chart showing the average proportion of Firmicutes, Bacteroidetes, Actinobacteria, Proteobacteria and all other phyla in 8-week old mice. (B-E) Quantification of the phyla Firmicutes, Bacteroidetes, Actinobacteria, and Proteobacteria. (F) Heatmap of the relative abundance of colonic microbes (Genus level). (G) Principal coordinates analysis (PCoA) plot of microbiota composition (Genus level). Data is shown as mean $( \pm 95 \% \mathrm{Cl})$ and a T-test was used to measure specific microbiome species abundance between groups. Adjusted p-value $>0.05$ was used as significant threshold.

Figure 2. Myeloid Atg5 expression prevents excessive IFNy-mediated intestinal inflammation. DSS-induced colitis and T cell response in Atg5-Wt and Atg5 $\Delta$ Mye mice. (A) Percent weight loss between Atg5-Wt and Atg5 $\Delta$ Mye mice. (B) Disease activity index (DAI) as determined by weight loss, behavior, acute diarrheal response and mucosal bleeding. (C) Colon length after colitis. (D) Spleen weight after colitis. (E and F) Colonic Ifng and I/17a gene expression after colitis induction. (G and H) Colonic IFNy and IL-17 protein expression as determined by ELISA. (I and J) Percent of IFNy ${ }^{+}$and IL- $17^{+} \mathrm{CD} 4^{+} \mathrm{T}$ cells isolated from the $\mathrm{mLN}$ of colitic mice. Representative of two independent experiments, Graphs indicate mean ( $\pm S D)$. * $P<0.05,{ }^{* *} P<0.01$. Two-tailed unpaired Student's $t$ tests or by 2 -way ANOVA with Tukey's post hoc test.

Figure 3. Atg5 regulates IL-12 secretion in macrophages. Analysis of IL-12 secretion in macrophages. (A) Detection of IL-12 by ELISA from Atg5-Wt or Atg5 $\Delta$ Mye BMM after LPS and IFNy stimulation. (B and C) Detection of IL-12 by ELISA from Atg5-Wt (B) or Atg5 $\Delta$ Mye (C) BMM after LPS and IFNy stimulation in the presence or absence of Baf. A1. Representative of two independent of experiments. (D - F) 1-3 $\mu \mathrm{m}$ Z-stack images were performed on BMM stimulated with LPS, IFNy and Baf. A1 using immunofluorescence at 1.6 Zoom by a $63 \mathrm{X}$ oil immersion objective. (D) Atg5-Wt BMM were stained for LAMP1 (green) and IL-12p35 (red). (E) Atg5-Wt BMM were stained for ATG5 (red) and IL-12p35 (green). (F) Atg5 $\triangle$ Mye BMM were stained for LAMP1 (green) and IL-12p35 (red). Representative from 65 images from 15 slides from two independent of experiments. Arrows in images indicate puncta co-localizing with insets displaying enlargement of indicated region. Scale bars: $10 \mu \mathrm{m}$. Graphs indicate mean $( \pm \mathrm{SD})$. * $P<0.05,{ }^{* *} P<0.01,{ }^{* *} P<0.001$. Two-tailed unpaired Student's t tests. 
Figure 4. NBR1 and IL-12 interaction. Analysis of NBR1 and IL-12 interaction in macrophages. (A) Atg5-Wt BMM were stained for NBR1 (red) and IL-12p35 (green) after LPS and IFNy stimulation and the addition of Bafilomycin A1 (Top Row) or Brefeldin A (Bottom Row). (B) Quantification was performed using Pearson's correlation coefficient (co-localization) using image analysis. Representative of two independent of experiments and of 10 images from 5 slides. Arrows in images indicate puncta co-localizing with insets displaying enlargement of indicated region. Scale bars: 10 $\mu \mathrm{m}$. (C) Anti-IL-12p35 antibody co-immunoprecipitated NBR1 and IL-12p40, and anti-NBR1 antibody co-immunoprecipitated IL-12p35 and IL-12p40. (D and E) Protein docking between IL12A (PDB ID: 1F45) and NBR1. (D) the docking models and (E) ClusPro docking results for four candidate interaction models between 1F45 and four peptide fragments of NBR1 (PDB IDs: 1WJ6, 2L8J, 2MGW, and 2MJ5). (F and G) Effects of NBR1 knockdown on IL-12 secretion in Atg5-Wt or Atg5 $\triangle$ Mye BMM. Graphs indicate mean ( $\pm \mathrm{SD})$. * $P<0.05,{ }^{* *} P<0.01$. Two-tailed unpaired Student's $t$ tests.

Figure 5. Limiting IL-12 in mice with a selective Atg5-deficiency in myeloid cells restores the intestinal microbiota and alleviates inflammation Bacterial composition as assessed by 16S rRNA sequencing from freshly collected stool of Atg5 $\Delta$ Mye and Atg5 $\Delta$ Mye-IL12KO mice prior to colitis induction ( $n=5$ per group). (A) Principal coordinates analysis (PCoA) plot of microbiota composition (Genus level). (B) Heatmap of the relative abundance of colonic microbes (Genus level). A T-test was used to measure specific microbiome species abundance between groups. Adjusted p-value $>0.05$ was used as significant threshold. . (C) Percent weight loss between Atg5 $\Delta$ Mye and Atg5 $\Delta$ Mye-IL12KO mice. (D) Colon length after colitis. (E) Spleen weight after colitis. (F and G) Percent of IFNy ${ }^{+}$and IL-17 ${ }^{+} \mathrm{CD} 4^{+} \mathrm{T}$ cells isolated from the $\mathrm{mLN}$ of colitic mice. Graphs indicate mean $( \pm S D) .{ }^{*} \mathrm{P}<0.05,{ }^{* *} \mathrm{P}<0.01$. Two-tailed unpaired Student's t tests or by 2-way ANOVA with Tukey's post hoc test. 


\section{Supplementary Information}

\section{Non-autophagy role of Atg5 and NBR1 in unconventional secretion of IL-12 prevents gut dysbiosis and inflammation}

Seth D. Merkley et al.,

Contents: Supplementary materials and methods, supplementary figures, supplementary figures legends, and supplementary tables

Cells and tissue preparation. Mesenteric lymph nodes $(\mathrm{mLN})$ were collected and manually homogenized into single cell suspensions in RPMI prior to plating and 4-hour stimulation with PMA (50 ng/mL), lonomycin (500 ng/mL), Brefeldin A/GolgiPlug (1:1000, BD Biosciences), and Monesin/GolgiStop, (1:1000, BD Biosciences) in preparation for intracellular cytokine staining and analysis by flow cytometry. Colon samples were cryopreserved in RNA-Later (Invitrogen), or cultured in RPMI for 4 hrs for cytokine analysis by ELISA. The histopathological evaluation was performed on the mouse colon sections using Hematoxylin and Eosin ( $H$ and $E)$ stained slides after formalin fixation. Standard five-micron thick $H$ and $E$ sections obtained from paraffin embedded blocks fixed in $10 \%$ formalin were used for assessment. The large intestine of the mice was embedded in paraffin using the 'swiss-roll' technique. The generation of BMM were prepared as briefly described, marrow was collected from the femur and tibia, washed and differentiated in DMEM (Gibco), FBS (VWR), and murine L929-fibroblast supernatant containing CSF-1 for 10 days, after which cellular morphology was evaluated to confirm differentiation. BMM's rested for 16 hours in media without CSF-1 prior to stimulation as specified for each experimental procedure below where relevant. All reagents used in cell isolation, culture, and stimulation are listed in Table S1. Flow cytometric protocol is described below, and all antibodies used for flow cytometric analysis are included in Table S7.

\section{RNA Isolation, Quantification, and RT-qPCR}

RNA isolation was performed on cells or tissues cryopreserved in RNA-Later (Invitrogen) using the RNA Purelink Minikit (Invitrogen) according to the manufacturer's protocols. RNA was quantified on Nanodrop2000 and all samples yielded a 260/280 of $2 \pm 0.15$. cDNA synthesis was performed using Oligo(dT) Primer and SSIV Reverse Transcriptase in the presence of 
Cloned Ribonuclease Inhibitor (all ThermoFisher). Reverse transcription reaction and RT-qPCR runs utilized Taqman MasterMix (ThermoFisher) on a viiA7 Thermal Cycler (ThermoFisher) using QuantStudio 7. RT-qPCR primers and reagents used are listed in Table S3.

\section{ClusPro web server}

The ClusPro web server for protein-protein docking was utilized to assess the interaction between IL-12p (PDB ID: 1F45) and NBR1 (PDB IDs: 1WJ6, 2L8J, 2MGW, and 2MJ5). https://cluspro.org/jobdetail.php?job=458409 https://cluspro.org/jobdetail.php?job=458405 https://cluspro.org/jobdetail.php?job=458404 https://cluspro.org/jobdetail.php?job=458403

siRNA knockdown, Western blot, co-immunoprecipitation analysis and protein detection assays

Small interfering RNA knockdowns were achieved using Amaxa Mouse Macrophage NucleofectorTM Kit (Lonza). Nucleofection was performed on Nucleofector 2b Device (Lonza) per manufacturer's protocols, using $20 \mu \mathrm{M}$ reconstitutions of Non-Targeting (Dharmacon) and 5 $\mu \mathrm{M}$ reconstitutions of NBR1 (Dharmacon) siRNA. Following Nucleofection, cells were plated and rested for 16 hours prior to stimulation. All macrophages were stimulated with LPS (500 ng/mL), IFNy $(10 \mathrm{ng} / \mathrm{mL})$ for 6 hours, with one of two duplicates also receiving BafA1 for 5.5 hours. siRNA reagents are listed in Table S5. All ELISA were performed using Quantikine ELISA Kits (R\&D) according to the manufacturer's specifications. For all analyses, undiluted cell media was collected immediately prior to cell harvesting and placed on ice prior to freezing. ELISA quantification was performed on Synergy Neo2 (BioTek) and plate washes using Quantikine wash buffer were performed on Multiwash Advantage (Tricontinent). All reagents used were taken from the Quantikine kits listed in Table S6. For flow cytometry, cells were washed poststimulation with FACS Buffer [90\% by volume 1x PBS, (Life Technologies), 10\%FBS (VWR), and $0.05 \% 0.5 \mathrm{M}$ EDTA, (Invitrogen)], and incubated for 20 min with antibody stain, followed by further FACS wash, and fixation in 1\% PFA. To examine intracellular proteins, cells were permeabilize and incubated with intracellular cytokines and washed and resuspended FACS buffer. Sample analysis was performed on LSR Fortessa (BD Biosciences). Antibodies used for flow cytometric analysis are listed in Table S7. For immunoblots, after stimulation, cells were washed in 1x PBS and lysed in $20 \mathrm{uL}$ of Pierce RIPA Lysis Buffer (ThermoFisher). All samples were boiled for $5 \mathrm{~min}$ at 65C in 1:1 Pierce RIPA Buffer: 2x Laemmli Buffer prior to gel electrophoresis at 90V (10\% Mini-PROTEAN® TGX ${ }^{\text {TM }}$ Precast Protein Gels, Mini-PROTEAN® Tetra Vertical Electrophoresis Cell for Mini Precast Gels, 2-gel, BioRad). Immunoblot transfer used the Trans-Blot ${ }^{\circ}$ Turbo ${ }^{\mathrm{TM}}$ Transfer System (Bio-Rad), and all blots were probed in $5 \%$ dry 
milk. All blots were imaged on Odyssey Clx (Licor Biosciences). For co-immunoprecipitated of IL-12p35 to NBR1 and IL-12p40 or NBR1 to IL-12p35 and IL-12p40, lysates were incubated with protein $A / G$ magnetic beads with $2 \mu$ g of anti-IL-12p35 or anti-NBR1 antibody or isotype control for 4 hours at $4^{\circ} \mathrm{C}$. The bead-antibody complexes were washed with cold PBS followed by incubation with whole cell lysates overnight at $4^{\circ} \mathrm{C}$. Following washes with lysis buffer and cold PBS, the bead-immune complexes were then resuspended in Laemmli's sample buffer and boiled for 5 minutes. Samples were then prepared for immunoblot analysis. All antibodies used for Western Blot are listed in Table S8. 


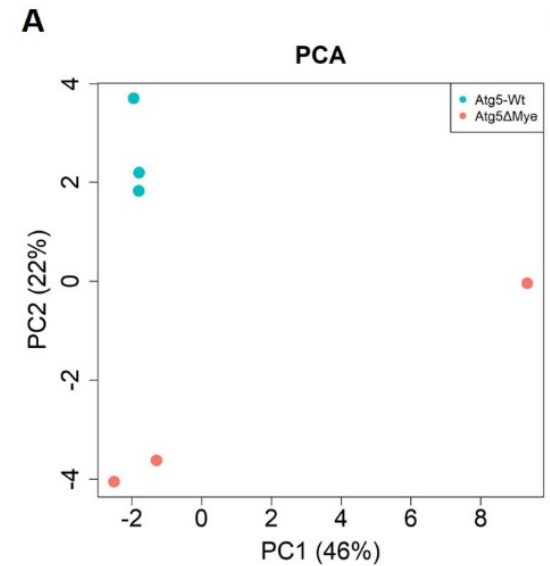

B

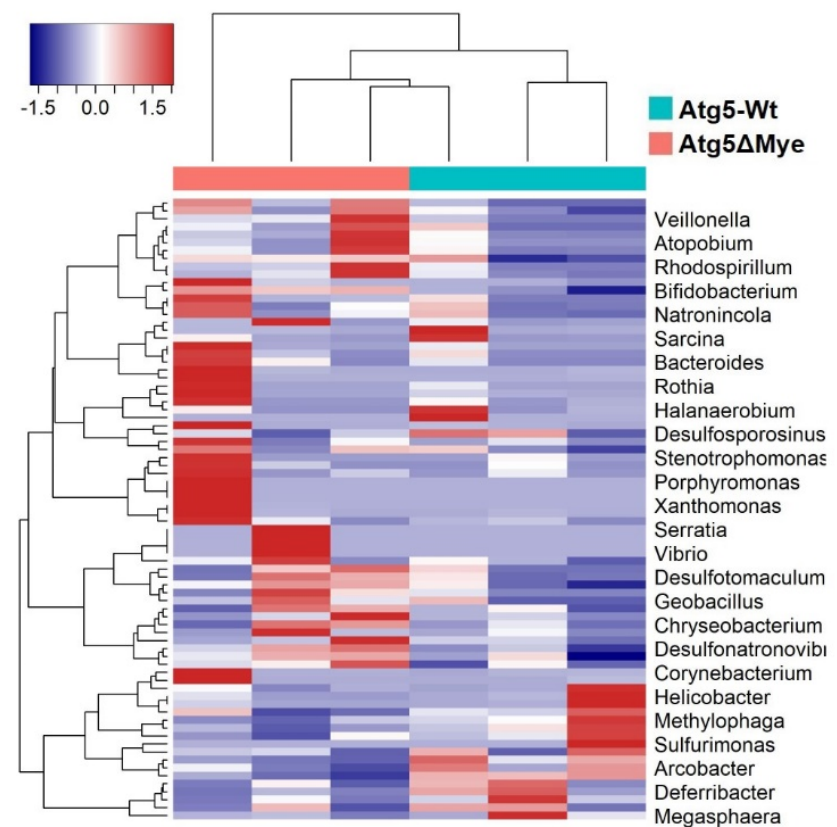

C
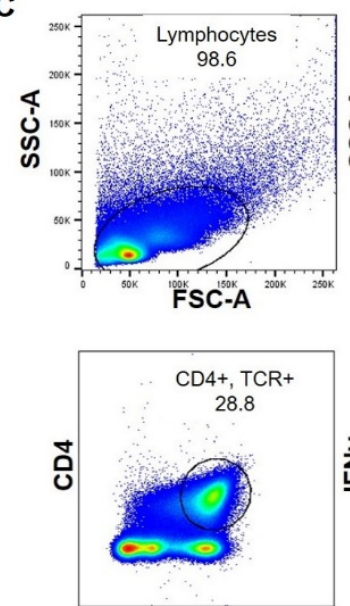

TCR

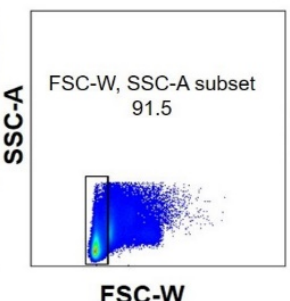

FSC-W

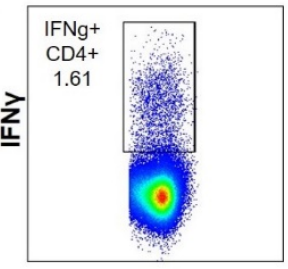

CD4

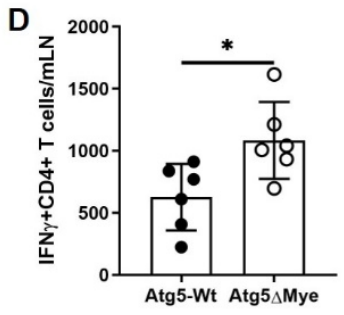

E

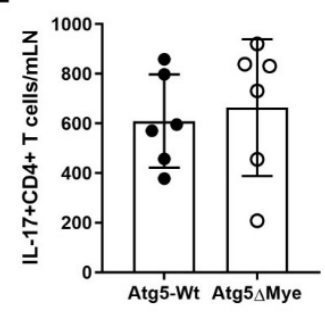

$\mathbf{F}$

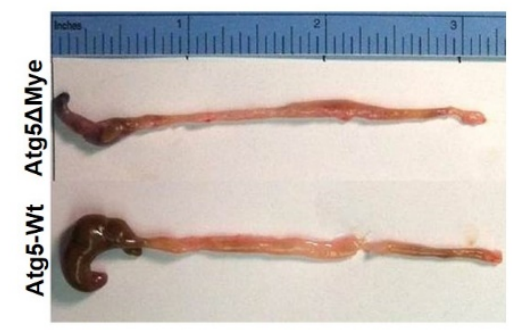

$\mathbf{G}$
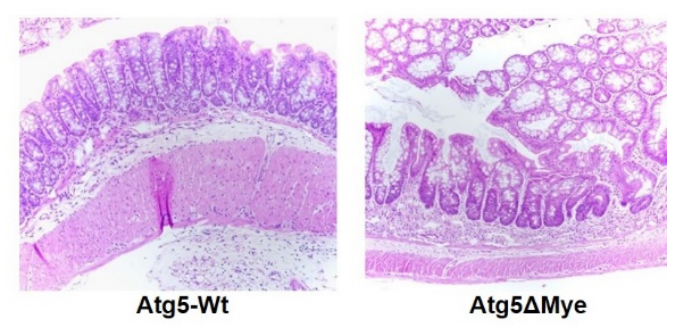

Supplementary Figure 1. Steady State $C D 4^{+} \mathrm{T}$ cell polarization and colitic response in Atg5cKO mice. (A) Principal coordinates analysis (PCoA) plot and (B) heatmap of microbiota composition in female mice (Genus level). (C) Flow cytometric gating of $\mathrm{mLN} \mathrm{CD4}^{+} \mathrm{T}_{\text {cells for }}$ intracellular cytokine staining. Representative dot plots of intracellular IFNy expression in $\mathrm{mLN}$ $\mathrm{CD}^{+}{ }^{+} \mathrm{T}$ cells isolated from Atg5-Wt and Atg5 $\Delta$ Mye mice. (D and E) Graph of IFNy and IL-17 ${ }^{+}$ $\mathrm{CD}^{+} \mathrm{T}$ cells isolated from the $\mathrm{mLN}$ of Atg5-Wt and Atg $5 \Delta$ Mye mice. (F) Representative gross anatomy of the cecum and colon of colitic Atg5-Wt and Atg5 $\Delta$ Mye mice. (G) H\&E staining of colons. Representative of two-three independent experiments, Graphs indicate mean ( $\pm S D)$. Student's t test, $\mathrm{P}<0.05$. 

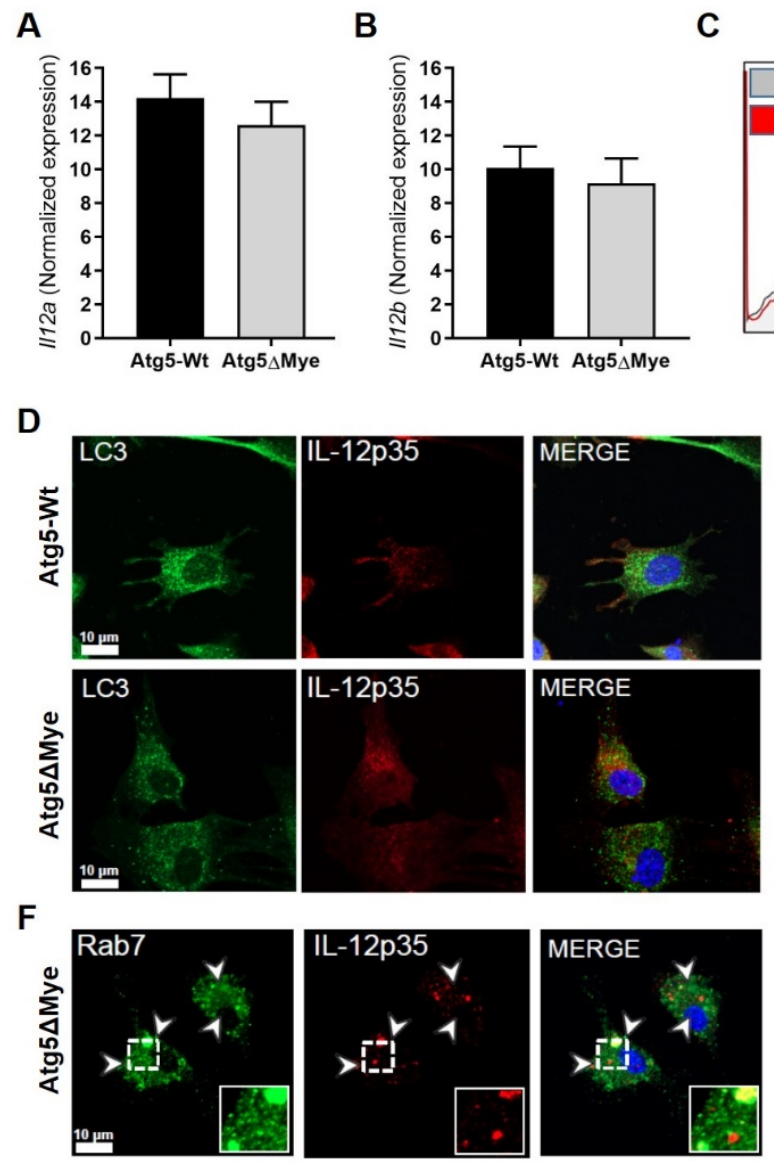

C

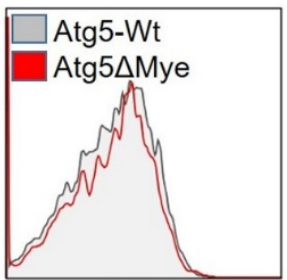

IFNyR

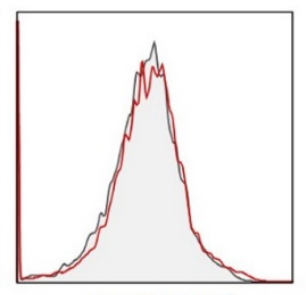

TLR4/MD2

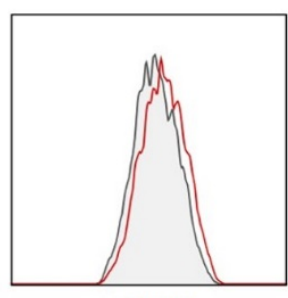

CD14
E
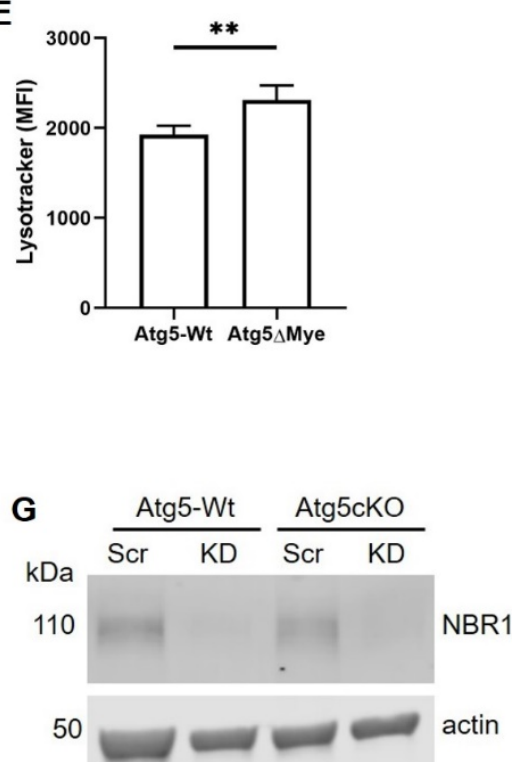

Supplementary Figure 2. Regulation of IL-12 secretion in macrophages. (A) /112a and (B) $1 / 12 b$ gene expression in unstimulated macrophages. (C) Representative histograms of cell surface expression on IFNYR (left), TLR4/MD2 (center), and CD14 (right) between unstimulated Atg5-Wt (gray) and Atg5 $\Delta$ Mye (red) macrophages. (D) Atg5-Wt and Atg5 $\Delta$ Mye macrophages were stained for LC3 (autophagosome marker) and IL-12p35 (subunit of cytokine IL12) after LPS, IFNy and BafA1. Representative from 20 images from 5 slides. (E) Mean fluorescence intensity (MFI) of Lysotracker green in unstimulated Atg5-Wt and Atg5 $\Delta$ Mye macrophages. (F) Atg5 $\Delta$ Mye macrophages were stained for Rab7 (late endosome marker) and IL-12p35 (subunit of cytokine IL12) after LPS, IFNy and BafA1. Immunoblot of IL-12p35 and actin expression in Atg5-Wt and Atg5 $\triangle$ Mye macrophages after stimulation with LPS and IFNY or LPS, IFNy and BafA1. Representative from 20 images from 3 slides. Arrows in images indicate puncta colocalizing with insets displaying enlargement of indicated region. (G) Immunoblot of NBR1 expression for scrambled (Scr) or knockdown (KD) siRNA targeted of NBR1 in Atg5-Wt and Atg5 $\Delta$ Mye macrophages after stimulation with LPS and IFNy. Representative of two-three independent experiments, Graphs indicate mean $( \pm S D)$. 
A Atg5cko

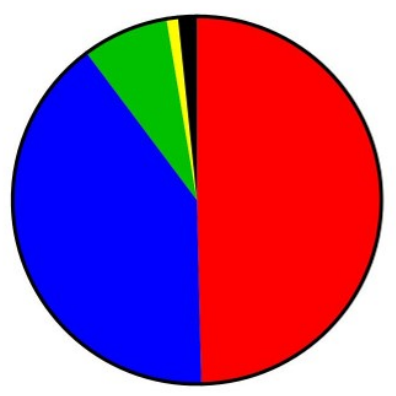

B

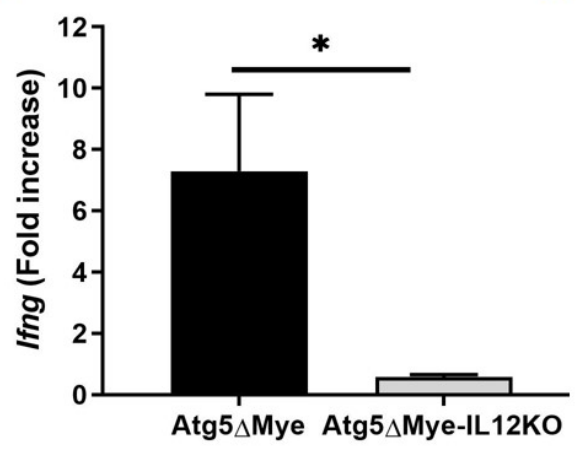

C
Atg5 $\Delta$ Mye-IL12KO
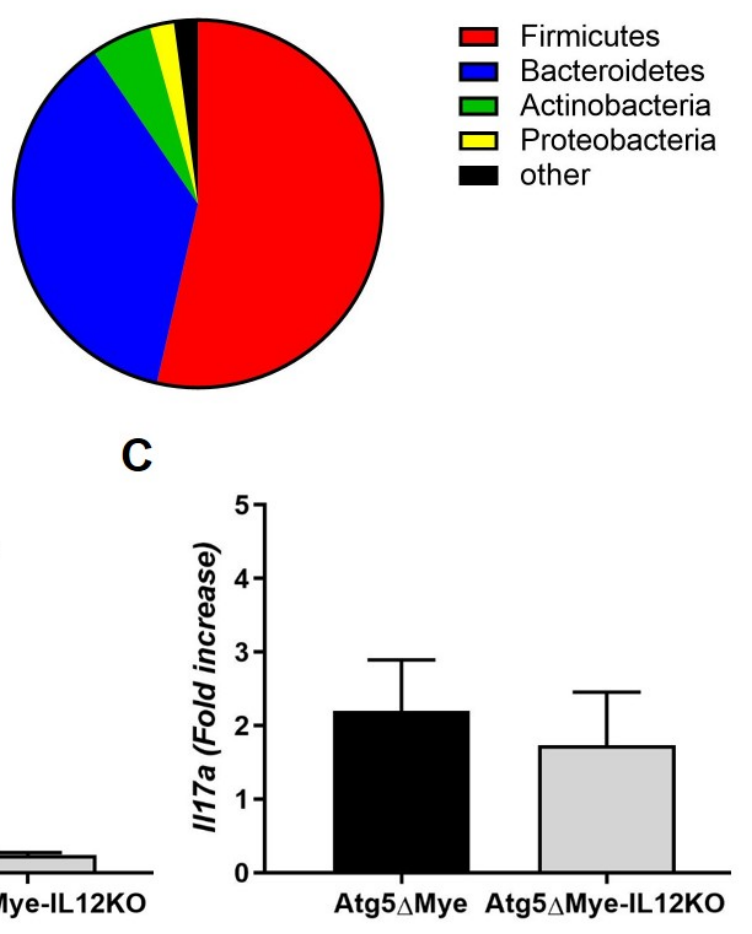

D

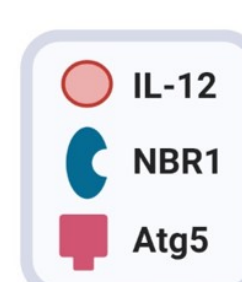

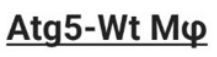

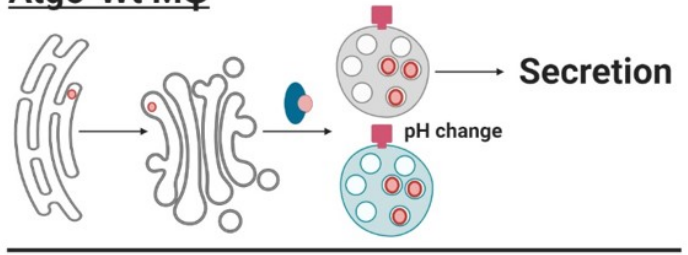

Atg $5 \Delta \mathrm{Mye} M \varphi$

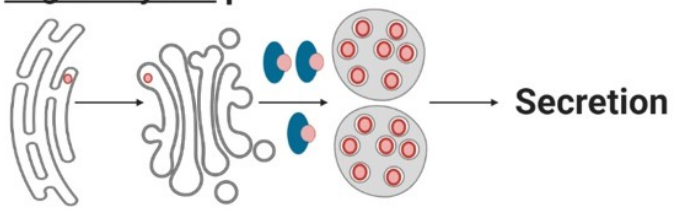

ER Golgi L.E. 
Supplementary Figure 3. Comparison of Atg5 $\Delta$ Mye and Atg5 $\Delta$ Mye-IL12KO mice. Metagenomic sequencing and $16 \mathrm{~S}$ profiling of DNA extracted from freshly collected stool of Atg5 $\Delta$ Mye and Atg5 $\Delta$ Mye-IL12KO mice ( $n=5$ per group). (A) Pie chart showing the average proportion of Firmicutes, Bacteroidetes, Actinobacteria, Proteobacteria and all other phyla in 8week old mice. (B and C) Colonic Ifng and I/17a gene expression after colitis induction. (D) Graphical abstract (BioRender). Representative of two independent experiments, Graphs indicate mean $( \pm S D)$. ${ }^{*} P<0.05$, Two-tailed unpaired Student's $t$ tests. 